\title{
RELATION OF IODIN TO THE STRUCTURE OF HUMAN THYROIDS
}

\author{
liELATION OF IODIN AND HISTOLOGIC STRUCTURE TO DISEASES IN GENERAL; \\ To EXOPHTHALMIC GOITER; TO CRETINISM AND MYXEDEMA** \\ DAVID MARINE, M.D., AND C. H. LENHART. M.D. \\ CLEVEIAND, OHIO \\ INTRODUCTION
}

Throughout the course of our studies on the formation of goiter it has been our aim to collect all the data possible as to the incidence, kinds and nature of the thyroid changes in animals so that when human thyroid changes were taken up at least some fundamental conclusions could be available as a point of departure. Nevertheless, while the supplanting of indirect and accidental observations on man by the direct observations on animals is the modern and logical way of approaching a medical problem, proper regard must always be had for the difference arising out of the different positions of the different animals in the biological scale of animal life, even though evidence is fast accumulating that their pathology is quite as applicable to man as their physiology, considering their position in the biological scale. This method of approach is particularly desirable in the case of the thyroid, since the advance of our knowledge of thyroid diseases has been restricted by attempting to use human material as a basis of study. This is due (apart from the indirect and accidental nature of such observations) to the fact that complicating factors are so common and modifying conditions so frequent that pure types are not encountered with sufficient frequency in the experience of any one observer to enable him to emphasize their importance.

In the present work we first attempted to use human material, but were forced to turn back and study series of dog, sheep, pig and ox thyroids in order to find basic types of anatomical changes. Therefore, the observations on human thyroid changes are compared with similar changes oocurring in the above-mentioned animals. The results of these comparisons have shown a surprising uniformity both in the iodin content and in the histological structure for all these animals-man, dog, sheep, ox and pig.

* From the H. K. Cushing Laboratory of Experimental Medicine, Western Reserve University. 


\section{ANATOMICAL CLA SSIFICATION}

'The confusion that at present exists throughout all phases of thyroid changes can be inferred from the vast literature that has arisen around one phase-namely, exophthalmic goiter-in the endeavor to establish the fact that in every true case of this disease there occurs active hyperplasia of the thyroid. And, even in this single phase, there are still widely different opinions. All the other phases of thyroid changes are more or less indefinite.

Virchow fully recognized the confusion existing at that time and the errors to which it was Jeading when he wrote: "With reference to true goiter the opinion has long been held that it comprises a series of definite species (struma iymphatiea, crstica, ossea, rasculosa, etc.) which develop independently of each other. This is wrong. All these so-ealled varieties are none other than different mores of development of essen-

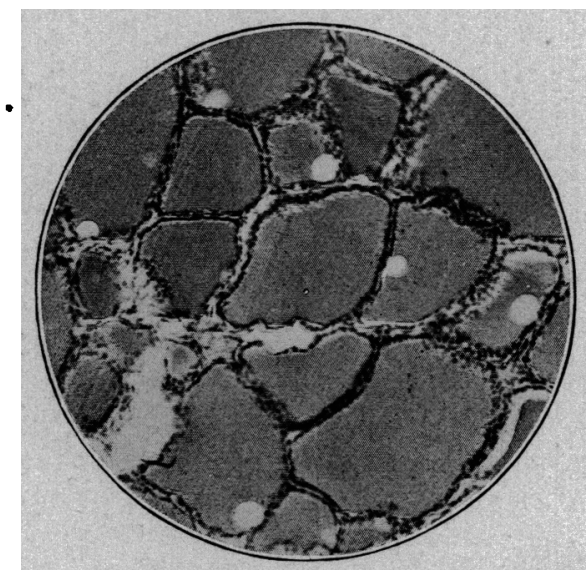

Fig. 1.-Normal thyroid (human). From a male, white subject. aged 40, dead of aortic stenosis. Iodin per gram of dried thyroid in milligrams-2,861. The sections represented in these illustrations were taken from the routine files of our human material. This material was hardened in 4 per cent. formalin. The sections were cut in celloidin and stained with hematoxylin and eosin. The magnification is the same in all, viz., Leitz, ocular IV, objective III $=95$ diameters. Figures 1 to 4 represent the "Normal" or "Primary" series of hyperplasias.

tially the same form of goiter. They mean only different forms of terminal conditions or metamorphoses which can be combined with one another in the same tumor, and a very large and striking variety of these metamorphoses may exist in the same tumor."

Since Virchow wrote these words the adrent of operative removal of goiters and the extensive reports based on this highly complicater! material have in general tended to complicate the classification further.

1. Virchow. Die krankhaften Geschwiilste, 1863, iii, 4. 
Two major causes have assisted in this confusion. First, as Virchow pointed out, the secondary or complicating changes have been raised to the importance of the primary changes-for example, such terms as "fibrous," "cystic" or "hemorrhagic" goiter have been placed on the same plane with parenchymatous (actively hyperplastic) goiter. Second, in the correlation of the clinical phenomena with the anatomical changes and the development of the clinical-pathological classification the fact has nol always been borne in mind that very great anatomical changes may occur in a short space of time and that the clinical phenomena do not necessarily change to the same extent; as, for example, the typical active thyroid hyperplasia of exophthalmic goiter may revert to a pure colloid condition within a month and the clinical picture remain that of a well-defined case of exophthalmic goiter. We have repeatedly observed this change.

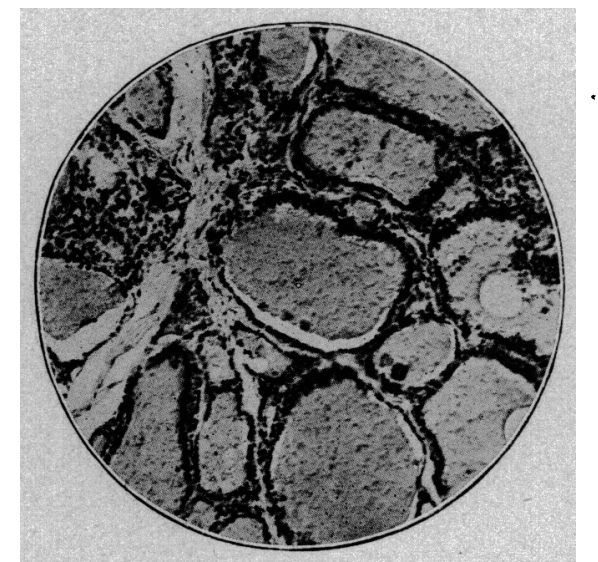

Fig. 2.-Early glandular hyperplasia. From a male, white, healthy subject, aged 30 , dead of fracture of the skull, from an accidental fall. Iodin per gram of dried thyroid in milligrams $=0.877$.

In the lower animals where these various secondary or complicating factors are reduced to a minimum it is quite easy to convince oneself by examining any large series of glands that there are fundamental types of thyroid changes concerned in the production of true goiter. These fundamental types are (1) the normal thyroid, (2) the actively hyperplastic thyroid (all degrees) and (3) the colloid thyroid.

With these fundamental types established, the problem of bringing the human thyroid changes into relationship with them is not difficult, although there remains in any large series of human thyroids and, to a lesser extent, of dogs' thyroids, a considerable group of glands in which the anatomical changes are so extensive and complicated as to bear little 
resemblance to the primary types. 'This is especially true of the human operative material, in which uncomplicated forms are seen only in the active hyperplasias of childhood, puberty, pregnancy and exophthalmic goiter or in the colloid glands resulting immediately therefrom.

From an anatomical material consisting of $3 \% 0$ human, $850 \mathrm{dog}$, 70 sheep, 67 ox and 26 pig thyroids which we have personally collected and examined, together with a fair review of the literature, the following general schema of anatomical changes has been deduced:

I. Normal 'Thyroid.

II. Active Hyperplasias.

1. Prenatal-may terminate in:

(a) Fibrosis-atrophy.

(b) Colloid.

2. Childhood-may terminate in:

(a) Fibrosis-atrophy.

(b) Colloid.

3. Puberty-may terminate in:

(a) Exophthalmic goiter, fibrosis-atrophy.

(b) Colloid.

4. Pregnancy-may terminate in:

(a) Exophthalmic goiter, fibrosis-atrophy.

(b) Colloid.

5. Exophthalmic goiter-may terminate in:

(a) Fibrosis-atrophy.

(b) Colloid.

111. ('olloid glands.

1. Active hyperplasial.

(a) Simple hyperplasia-may terminate in:

(i) Exoplithalmic goiter.

(ii) Colloid.

(b) Exophthalmic goiter-may terminate in:

(i) Fibrosis-atrophy.

(c) Colloid.

(ii) Colloid.

IV. Atrophies.

1. Infantile.

2. Supervening in exophthalmic goiter, tuberculosis, obesity (Dercum's disease?), etc.

3. Physiological (old age).

V. Regeneration (hyperplasia).

VI. Degeneration.

1. Hyaline.

2. Calcareous.

3. Amyloid, ete.

VII. Inflammations.

VIII. Tumors.

1. Benign.

(a) Fetal adenoma.

(b) Simple adenoma.

2. Malignant.

(a) Carcinoma.

(i) Originating from fetal adenoma.

(ii) Glandular carcinoma. 
IX. Complications.

(b) Sarcoma.

(c) Endothelioma, ete.

1. Hemorrhage and its sequelix.

2. Cysts, etc.

This general outline or skeleton of the major types of changes occurring in the thyroid differs somewhat from the usual ones of text-books in several important particulars. First and most important perhaps is that colloid glands have been removed from the group of degenerations and placed on the same plane with normal glands and the hyperplasias. This was the result of both an anatomical and experimental study. ${ }^{2}$

Second, it indicates the sequence of changes occurring in the gland, e. g., colloid glands are placed after the active hyperplasias because it has

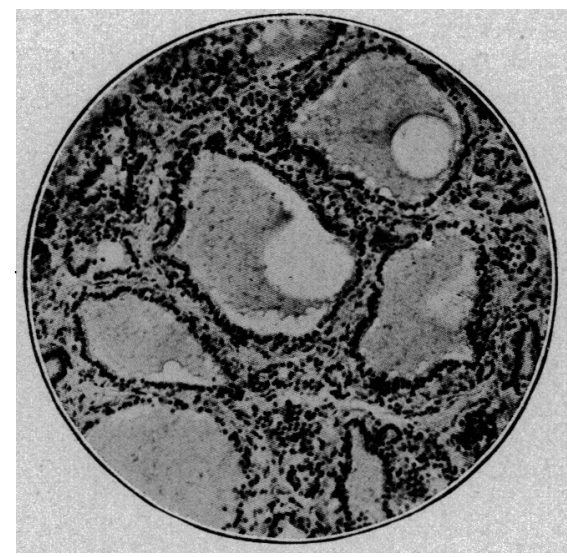

Fig. 3.-Moderate glanclular hyperplasia. From a male, white subject, aged 31, dead of typhoid fever with intestinal perforation. Iodin per gram of dried thyroid in milligrams $=0.615$.

been shown that all colloid glands have at one or more times been in the stage of active hyperplasia.

Iikewise atrophies, apart from the physiological (senile) form, are in all probability always preceded by a greater or lesser degree of active hyperplasia. ${ }^{3}$

In the present communication we are concerned only with normal actively hyperplastic and colloid glands, inasmuch as these are the only fundamental types concerned in the production of true goiter. Certain relations with the remaining groups of the general schema will, however, be pointed out in their proper places.

2. Von Brums: Beitr. \%. klin. Chir., 1896, xvi, 521. Marine and Lenhart: Johns Hopkins Hosp. Bull., 1909, xx, 131.

3. Ord, W. M.: Brit. Med. Jour, 1898, ii, 1473, Howard, C. P.: Myxedema. Jour. Am. Med. Assn., 1907, xlviii, 1325. 
The anatomical descriptions to follow will, in the main, be confined to the human thyroid, inasmuch as extended descriptions of similar changes in other animals have already appeared."

\section{NORMAL THYROID*}

The normal human thyroid ${ }^{5}$ differs histologically in no essential way from similar glands in the dog, sheep, ox, pig or horse. In the past histologists have differed somewhat as to the characteristics of normal glands, but these differences were dependent largely on the egional and accidental circumstances of the material used. The more recent descriptions given by Müller, ${ }^{6}$ Bozzi, ${ }^{7}$ and Ebner ${ }^{8}$ show a general agreement. From these authors' descriptions, however, it can be seen that no sharply

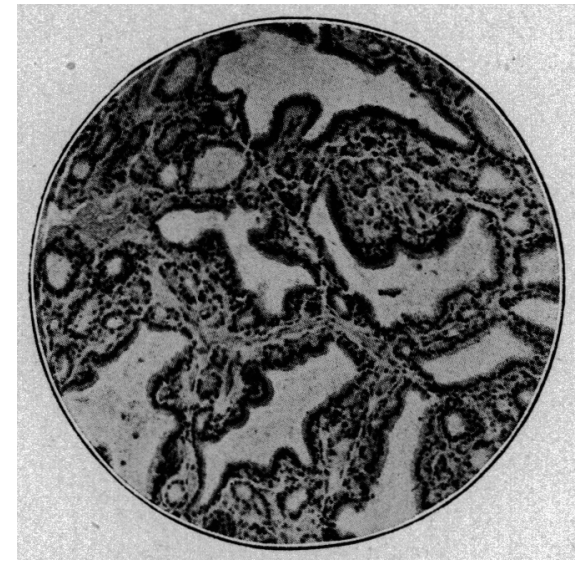

Fig. 4.-Marked glandular lyperplasia. From a case of exophthalmic goiter in a female subject, aged 22, dead following operation. Iodin per gram of dried thyroid in milligrams $=0.292$.

cut, terse description of the histology is universally accepted. This is to be expected in regard to a gland like the thyroid, which reacts so quickly

\footnotetext{
* See Figure 1.

4. Marine: Cleveland Med. Jour., 1907, vi, 45. Marine: Johns Hopkins Ilosp. Bull., 1907, xviii, 359. Marine and Williams: The relation of iodin to the structure of the thyroid gland. 'TnE Arehives INT. MED., 1908, i, 349.

5. The parathyroid glands have been examined in all autopsy specimens and it may be stated that we have found them remarkably constant in number and position when one considers their normal number (four) and their size. They usually partake of the color of the thyroid, i. e., are pale yellow in the lighter red and brown yellow in the darker red thyroids. We have seen no evidence suggesting that they react anatomically with the thyroid in its goitrous changes and we believe that they are quite independent structures.

6. Miiller, L. R.: Beitr. z. path. Anat. u. allg. Path., 1896, xix, 127.

7. Bozzi: Beitr. z. path. Anat. u allg. Path., 1895, xviii, 125.

8. Ebner: Koelliker's Handbuch der Gewebelehre des Menschen. Leipzig. 1899 , iii, 316.
} 
to the many changes and alterations in the body metabolism. It was pointed out by Hale White that if one examined any large series of human thyroids he would find great variations in the histological appear. ance in subjects that, during life, showed no manifestations of diseases known to be associated with thyroid changes. This observation has been confirmed by all subsequent observers.

The perfectly normal, adult thyroid weighs between 20 and $30 \mathrm{gm}$. This is lower than the weight usually stated (30 to 40) and applies to the seacoast type, for there is no doubt that in goitrous districts much larger glands are considered normal, although from our observations we believe that all such glands have at one time or another shown hypertrophic changes, and if histologic examination shows any evidence to that effect we class them as colloid glands.

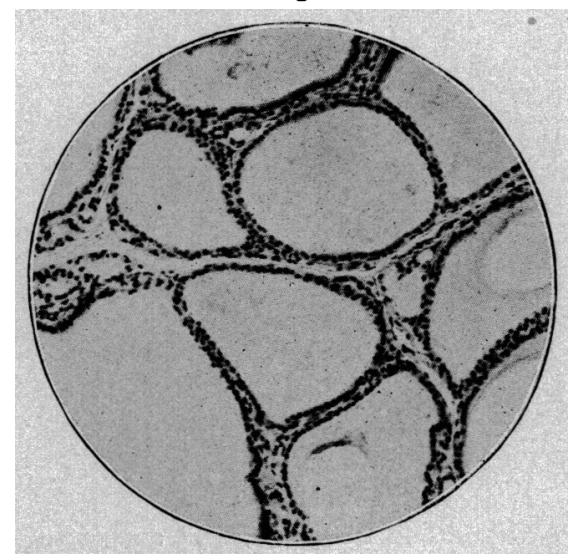

Fig. 5.-Colloid-early glandular hyperplasia. From a female, aged 21 , dead of eclampsia with Cesarean section. Iodin per gram of dried thyroid in milligrams $=0.815$. Figures 5 to 7 represent the "Colloid" or "Secondary" series of hyperplasias. (When this paper was sent to the publishers we had not obtained an uncomplicated specimen of colloid marked glandular hyperplasia.

The lateral lobes are in general symmetrical and of uniform size. though slight variations are not infrequent. So also with the isthmus and pyramidal portion. The outer fibrous areolar capsule is thin and strips easily, leaving a slightly lobulated smooth surface. The capsule proper is thin and translucent, and thickened portions (trabeculæ) cxtend into the gland, mark out the lobules, and support the blood and lymph vessels. The general color varies from a pale amber red to a bright amber red. On section the follicles can just be distinguished with the naked eye and vary greatly in diameter $(0.3$ to $0.5 \mathrm{~mm}$.). They are filled with a clear amber-yellow viscid colloid.

9. White, Hale: Med. Chir. Tr., 1888, lxxi, 181. 
Microscopically the follicles are in general round or oval closed spaces of somewhat irregular size. They are lined with a single layer of flat cubical or, at most, cubical epithelium (high cubical or columnar types of epithelium always indicate hypertrophy). The cells are quite regular in size and in certain specimens the so-called "chief" and "colloid" cells described by Langendorf ${ }^{10}$ can be made out. These changes probably represent different secretory activities of the cells. The nuclei are small, basal, darkly staining and vesicular. The colloid lies in contact with the free border of the epithelial cells. It is homogeneous and stains deeply with cosin. The colloid of adjacent follicles may not stain with the same intensity, and colloid-like material is frequently to be seen in the lymphatic spaces - an observation usually taken as evidence that the lymphatics form the normal paths of exit for the colloid. ${ }^{11}$ The

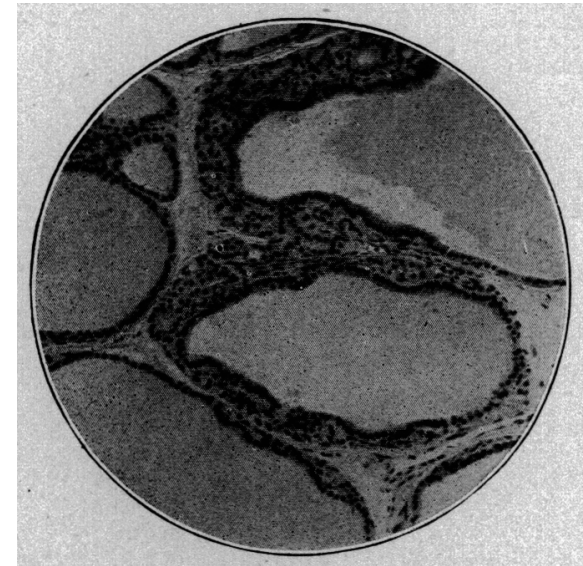

Fig. 6.- Colloid-moderate glandular hyperplasia. From a male, while subject, aged 22; clinical diagnosis; exophthalmic goiter. Patient operated on; recovered. Iodin per gram of dried thyroid in milligrams $=0.360$.

blood and lymph vessels, though forming rich networks about the follicles, are not prominent, nor are the larger vessels of the trabeculæ an! capsule thick-walled and tortuous as in the colloid goiters.

\section{ACTIVE THYROID HYI'ERPLASIAS*}

There is no essential difference between the forms scen in human and those seen in dog, sheep, ox or pig thyroids. Pure types of hyperplasia are, of course, less frequently observed in man. Detailed descrip-

10. Langendorf: 3iol. Centralb., 1889-90, ix, 426 .

11. Baber: Quart. Jour. Micr. Sc., 1877, new series, xvii, 204. Hürthle: Arch. f. d. ges. Physiol. (Pflïger's), 1894, lvi, 1. Zeiss: Inaug. Diss. Strassburg, 1877.

*See Figures 2, 3, 4, 5, 6. 
tions of these changes in the dog, sheep and ox have already appeared and it remains only to outline those occurring in the human thyroid. Active hyperplasias, being the first or primary phase of goiter formation, are most frequently observed in the goiter-developing epochs-namely, childhood, puberty and pregnancy-although a great many thyroids show active hyperplasia when there is no clinical evidence of thyroir abnormality. The classical and perhaps best known example of thy roid hyperplasia in man occurs in exophthalmic goiter.

In man, just as in the lower animals, one observes all degrees of hyperplasia, from the very slightest changes from normal or colloid glands (hypertrophy) to the most marked epithelial proliferation (hyperplasia).

As has been discussed at some length in other publications (Marine and Williams ${ }^{4}$ and Marine and Lenhart ${ }^{2}$, it is necessary to recognize

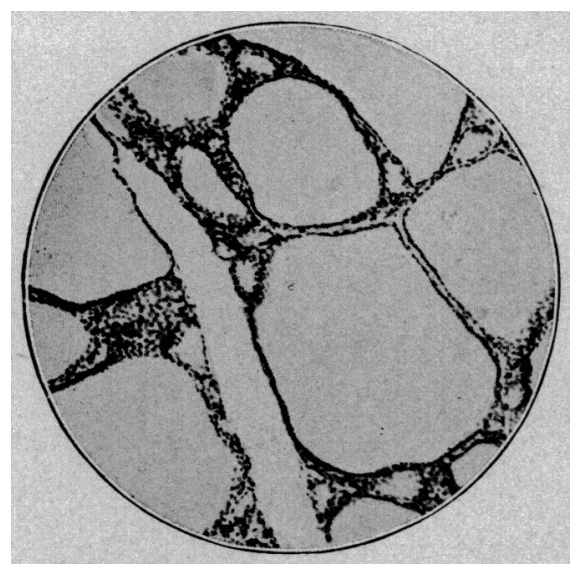

Fig. 7.-Colloid goiter. From a female subject, aged 19 ; case clinically diag. nosed as severe exophthalmic goiter; patient had been treated for past six months by the internal administration of iodin; operated on, recovered. Iodin per gram of dried thyroid in milligrams $=4.614$.

two series of hyperplasias-(1) normal (2), colloid. The normal series includes all cases of hyperplasia which are engrafted on normal glands and the colloid series of hyperplasias include all cases in which the hyperplasias are engrafted on colloid glands. This secondary hyperplasia (secondary in the sense that it is not the first time these glands have undergone active hyperplasia) is well recognized in human goiter, especially as the so-called "secondary exophthalmic goiter," and of late we have recognized that secondary hyperplasia occurs in colloid glands just as readily as primary hyperplasia occurs in normal glands, and as a result of the same causes, either with or without (usually without) the clinical signs of exophthalmic goiter. Since the conditions favorable to 
the development of colloid glands (variations in food, body nutrition, locality, etc.) more commonly affect man and dog, colloid glands and the several degrees of the colloid series of hyperplasias are more often seen in these animals.

For convenience of description and of analysis we have divided the two series (normal and colloid) into subgroups, as follows: (1) Normalcarly, early, early-moderate, moderate, moderate-marked and marked glandular hyperplasia; (2) colloid-early, colloid-early-moderate, colloidmoderate, colloid-moderate-marked and colloid-marked.

The early stages of hyperplasia are the most important, for the reason that the first change from the normal gland marks the first step in the formation of goiter, and it is now generally recognized that the primary phase of all true goiters is active hyperplasia (Virchow ${ }^{1}$ ).

Tracing the process of hyperplasia, the first change noted in the thyroid is an increased blood supply to the gland. The capsular vessels are dilated. They become tortuous. The capillaries surrounding the follicles are dilated and congested. The gland becomes larger and softer and takes on a brighter red color. Microscopically there is lessening of the stainable colloid; at first but palely staining, later vacuolization, and finally actual disappearance of the true colloid-its place being taken by a glandular albuminous débris in which are seen leucocytes and shed epithelial cells.

The flat-cubical or cubical epithelial cells of the normal or colloid glands at first become high cubical with larger and more vesicular nuclei; later they become columnar, and finally high columnar. Then, as hyperplasia takes place, infoldings and plications of the lining epithelium are formed. This process is apparently an attempt to increase the epithelial surface without undue general glandular enlargement. The connectivetissue framework of the capsule and trabeculæ increases. This is at first probably only a compensatory process to support the great increase of epithelial elements and the increased blood supply.

The now well-recognized and clear descriptions of the essential histological changes in exophthalmic goiter, which have been developed by Bramwell, ${ }^{12}$ Greenfield, ${ }^{13}$ Edmunds, ${ }^{14}$ Farner, ${ }^{15}$ Von Hansemann, ${ }^{16}$ Hirschlaff, ${ }^{17}$ Mac Callum, ${ }^{18}$ Ewing, ${ }^{19}$ Lewis, ${ }^{20}$ Wilson, ${ }^{21}$ and others, repre-

12. Bramwell: Atlas of Clinical Medicine, Edinburgh, 1892-3, ii, 91.

13. Greenfield: Brit. Med. Jour., 1893, ii, 1261.

14. Edmunds: Lancet, London, 1901, i, 1317, 1381, 1449.

15. Farner: Virchow's Arch. f. path. Anat., 1896, cxliii, 509.

16. Von Hansemann: Berl. klin. Wehnschr., 1905, No. 44a 65.

17. Hirschlaff: Ztschr. f. klin. Med., 1899, xxxvi, 200.

18. MacCallum: Johns Hopkins Hosp. Bull., 1905, xvi, 287.

19. Ewing: Tr. Assn. Am. Phys., 1906, xxi, 567.

20. Lewis: Surg., Gyn. and Obst., 1906, iii, 476.

21. Wilson: Am. Jour. Med. Sc., 1908, cxxxvi, 851. 
sent the most familiar type of extensive active hyperplasia in man, but by no means the most frequent one, since identical histological changes are observed in the prenatal, puberty and pregnancy thyroid enlargements. To sum up: The thyroid changes in all forms of active hyperplasia are characterized by an increase in the blood supply and the lymphatic drainage; a decrease in the stainable colloid; marked hypertrophy and hyperplasia of the follicular epithelium; a variable increase in the stroma, and frequently deposits of lymphoid tissue here and there throughout the stroma.

In addition to the necessity of establishing two series of hyperplasias -normal and colloid, as above mentioned-and the ready explanation it affords in many histological pictures of hyperplasia, there is perhaps another factor that modifies our interpretation of hyperplasias which has not been sufficiently emphasized in the published descriptions. It is the occurrence of atrophic changes. This type of atrophy seems to differ from simple cell atrophy in that there is a marked disturbance in the nucleus-plasma relationship, and, as it has been observed only in glands with marked hyperplasia from subjects that during life showed clinical signs of myxedema or cretinism, its significance will be discussed along with these diseases.

\section{COLLOID GLANDS*}

The third great natural division of thyroid changes are the colloid glands (goiters). In our human series it will be noticed (see Tables 8 and 1) that there are 25 colloid glands and 23 normal. This surprising proportion of colloid glands is due to two factors. First, in goitrous districts hyperplasias are much more common than normal glands (the proportions of hyperplasia to normal in our normal series' collection being 53 to 3 for dogs, 14 to 19 for sheep, 6 to 18 for pigs, 20 to 17 for cattle and 23 to 23 for man) and all reverted hyperplasias are colloid glands (goiters). Second, we have called all glands colloid that show any evidence of having previously undergone active hyperplasia. Thus there are many glands that, as regards size, shape, color, consistency, colloid and histological appearance, would ordinarily be considered normal. They are physiologically normal, but they show the marks of a previous hyperplasia, and for sake of strict anatomical analysis it is necessary to recognize these anatomical differences.

Pure colloid glands (goiters) present no essential differences in any of the animals examined. They differ essentially from normal glands in all these animals only in size (though, as has just been pointed out, they may be no larger than normal) and in showing the vestiges of pre-

\footnotetext{
* See Figure 7.
} 
vious hyperplasia. 'These marks of previous hyperplasia, however, are well-defined and characteristic. Their prominence in any given specimen depends on the degree and duration of hyperplasia and the lengti of time since the reversion occurred. These changes are to be found in the size and shape of the follicles, in the presence of sprig-like projections into the follicles in the more recent involutions (reversions), in the blood and lymph vessels, and in the stroma and capsule. The epithelium is normal (flat cubical), the stroma is increased, although to this statement there are exceptions depending on the extent of the fibrosis occurring during the active hyperplasia and the extent of the absorption which normally occurs during the process of reversion. Thus we have seen markedly cretinoid pups' thyroids, in which the stroma was so increased that the scattered thyroid follicles gave the gland the appearance of the endometrium, so resolve in the course of a month following the administration of iodin as to have all the appearances of a pure colloid gland with normal stroma. Such cases illustrate how rapidly the body can adjust physiological defects. The thickened thyroid capsule is likewise the inheritance from the preceding hyperplasia and varies greatly in thickness in different specimens. The arterial walls are always thickened and histologically show an obliterating endarteritis similar to that seen in the involuting thymus or uterus. Calcification is very common in these thickened walls, and even the veins may contain calcareous deposits in their walls. The most striking change in the veins and lymphatic trunks is the great lessening in their caliber. This is associated with some thickening of their walls. The stainable colloid is normal in appearance and distribution in the follicles. The follicles are in general nuuch larger than in normal glands, but this depends on the degree of hyperplasia preceding the involution (reversion), and perhaps also on other as yet ill-defined factors, as, for example, the cause of reversion and the duration of the process. If only a hypertrophy has preceded the involution (reversion), then it is scarcely possible to distinguish such a gland from normal. We have met several glands of which we could neither convince ourselves that the structure was normal nor offer definite proof of a previous hyperplasia. These glands we have called "normalcolloid" and have separated them for analytic purposes. The sprig-like projections into the follicles are the remnants of the infoldings or plications occurring during the preceding hyperplasia and there is evidence that these sprigs are slowly effaced in long-standing colloid glands (goiters).

Only brief mention in the way of explanation of the other divisions of the classification can be made here, inasmuch as they are not primarily concerned in the production of goiter and will be discussed in a later publication. 


\section{ATROPFY}

Atrophy is a normal senile process. The thyroid is most active in youth, as is also goiter formation. True goiter rarely develops after 45 years of age. ${ }^{22}$ Simple atrophy also occurs in many of the chronic diseases, and is particularly associated with chronic pulmonary tuberculosis. The special forms of atrophy leading to colloid glands, and consequent upon the hypertrophies and hyperplasias of puberty, menstruation and pregnancy, are best considered involutions (reversions).

The form associated clinically with the symptom-complex of myxedema, first recognized by Gull ${ }^{23}$ and later carefully described by Ord $^{24}$ and Hun and Prudden, ${ }^{25}$ is of particular interest in that it is a form of atrophy occurring in spite of attempts at hyperplasia and is apparently the result of sustained thyroid stimulation without intervening periods of physiological rest. It is coming to be more recognized that this form of atrophy is practically always preceded by hyperplasia, with or without the symptom-complex of exophthalmic goiter. This change is seen particularly in cases of exophthalmic goiter that are passing over into myxedema. Briefly, the histological changes are as follows: The epithelial cells lose the regular and uniform type characteristic of the usual hyperplasia and become irregular in size and shape. There is desquamation and piling up of the epithelial cells in the vesicles. The nuclei are in general enlarged, hyperchromatic and irregular in size and shape. Nuclear figures are observed, but the new formation of cells is not sufficient to offset the cell degeneration and the vesicles become smaller. The surrounding fibrous tissue is relatively, perhaps absolutely, increased, and, as the vesicles are reduced in size, they are more and more widely separated. The interstitial cirrhosis, we believe, is secondary and consequent on the destruction of the epithelial elements. We have frequently observed the milder forms of this type of atrophy in exophthalmic goiter thyroids and feel sure that it is more common than the literature reports indicate.

\section{REGENERATION}

Except for normal replacing of cells as they die-a process which is continually going on in most glandular tissues-regeneration is a compensatory process and hence is more aptly considered a part of the general group of hyperplasias. Regeneration occurs following partial destruction

22. Horsley: Brit. Med. Jour., 1892, i, 215.

23. Gull: Tr. Clin. Soc., London, 1874, vii, 180.

24. Ord: Med.-Chir. Tr., London, 1878, lxi, 57.

25. Hun and Prudden: Am. Jour. Med. Sc., 1888, xevi, 140. 
or removal of the thyroid, as has been amply shown for man and animals. ${ }^{28}$

The new-formed tissue may remain normal in structure, as occurs in young animals after partial removal with the administration of iodin, or it may take on the characteristics of true spontaneous hyperplasia, as in similar cases of partial removal without the administration of iodin. The two groups of "Regeneration" and "Hyperplasia" are so nearly a part of each other that it is impossible to distinguish sharply between them. To say that regeneration stops when the thyroid tissue has attained its normal amount is not in accord with all the known facts. The normal gland shows considerable variation in different subjects and, besides, there are at least two factors concerned: the first is the actual number of cells necessary to perform the thyroid functions under favorable conditions of nutrition and metabolism, and the second factor is the degree of cell proliferation which may occur in conditions of malnutrition or disturbed nutrition. Thus the statement sometimes made that compensatory regeneration does not exceed the normal size of the gland ${ }^{2 i}$ is not in accord with our present knowledge, for the reason that the extent of the cell proliferation in the thyroid depends on the physiological requirements of the animal and this can be markedly influenced by diet, iodin, etc.

\section{DEGENERATIONS}

Degenerations include calcareous, hyaline and amyloid changes and are never seen apart from other pathological processes, as hemorrhage, cyst formation, etc. These changes are very frequently seen in old colloid goiters, but they are always secondary changes and are never essential parts of the colloid transformation. Pure colloid goiters are not degenerative processes, as they have long been considered. They are more allied to the atrophies and are, properly speaking, involutions, since it is now definitely known that they obey all the known biological laws of normal glands (Marine and Lenhart²).

\section{INFLAMMATIONS}

Apart from a general view that all goiter is inflammatory in nature, true inflammations as we regard them to-day are rare. ${ }^{28}$ They may, how-

26. Wagner: Wien. med. Bl., 1884, vii, 771. Schiff : Arch. f. exper. Path. u. Pharmakol., 1884, xviii, 25. Halsted: Johns Hopkins Hosp. Rep., 1896, i, 373. Welch: Med. Rec., New York, 1888, xxxiv, 368. Horsley: Brit. Med. Jour., 1892, i, 215. Ribbert: Virchow's Arch. f. path. Anat., 1889, cxvii, 151. Sulzer: Ztschr. f. Chir., 1893, 191.

27. MacCallum, W. G.: The pathology of exophthalmic goiter. Jour. Am. Med. Assn., 1907, xlix, 115s.

28. Ewald, C.: München. med. Wchnschr., 1896, xliii, 634. 
ever, occur in the course of many of the infectious diseases, as lues, tuber. culosis, typhoid, influenza, ete. Inflammation has frequently followed injuries, as in the old treatment of goiter by iodin and iron injections. ${ }^{29}$

\section{TUMORS}

The most frequent tumor of the thyroid is the fetal adenoma, as described by Billroth, ${ }^{30}$ Bloodgood, ${ }^{31}$ and others. These are usually small, frequently multiple and may attain the size of one's fist. There are apparently several types or phases of these tumors, ranging from the type closely resembling fetal thyroid which gave rise to the name, to the welldifferentiated colloid-containing form. Likewise these tumors are known to undergo (reversion) involution to the colloid or quiescent state, in which they can not be differentiated from ordinary colloid goiter except for the smaller size of the alveoli and their complete encapsulation.

Aside from the above-described form one finds encapsulated adenomatous growths of well-differentiated thyroid tissue growing, in some instances, apparently independently of the rest of the thyroid gland and histologically resembling the well-differentiated cells of ordinary thyroid hyperplasia. Without any definite evidence, we are inclined to look on them as closely related to the fetal adenoma, being only a fully differentiated type.

Carcinoma of the thyroid is difficult of diagnosis microscopically. It has long been known that not infrequently one finds apparently benign types of thyroid tumor in what are undoubtedly metastases, and also there are cases reported in which metastatic thyroid tissue has been found with no evidence of a primary growth in the thyroid. Thus it is probable that we have not recognized some of these tumors, but, on the other hand, it is probable that there are tumors reported as carcinoma that are not. In our experience, however, carcinoma of the thyroid in man is rare. It would appear to be in some way related to the frequency of goiter, and even associated with goiter itself. Pick, ${ }^{32}$ working with the carcinoma of brook trout, was inclined to such a view. We have observed two types of thyroid carcinoma. One, histologically, closely resembles the fetal adenoma tissue and might be called malignant fetal adenoma. The other preserves the characteristics of differentiated thyroid tissue. Seven cases of carcinoma of the thyroid in old dogs have come to our notice. Three of the cases had lung metastases. In all there had been

29. Semon: Brit. Med. Jour., 1885, i, 715.

30. Billroth: Arch. f. Anat. Physiol. u. wissensch. Med., Berlin, 1856, 144.

31. Bloodgood: Surg., Gyn. and Obst., 1906, ii, 121.

32. Pick: Berl. klin. Wehnschr., 1905, xlii, 1536. 
long-standing goiters. In none was there accompanying sarcoma, as has been reported by Schöne. ${ }^{32}$ The epithelial changes were similar to those described by the above observer.

We have seen one case of lymphangioendothelioma probably originating in the thyroid, but no case of true sarcoma.

\section{ix. COMPLICATIONS}

Hemorrhage and its sequelæ are the most frequent secondary changes in goiter. Hemorrhage occurs more commonly in the colloid phase. It is dependent on trauma and overdistention of the alveoli with subsequent rupture of their walls. ${ }^{34}$ Hemorrhages occur in all animals in which colloid glands are seen and their relative natural frequency probably is the same, although it seems more common in dogs. Trauma, as in fighting and sudden violent excrtions causing venous engorgement, perhaps plays an important rôle in dogs. Cysts are the most important sequels of hemorrhages and we are inclined to believe with Bradley ${ }^{35}$ that the great variety of cysts seen in the thyroid are probably primarily of hemorrhagic origin. Occasionally small hemorrhages are seen in otherwise histologically normal glands. Hydatid cysts are occasionally reported.

It seems clear from the preceding anatomical discussion that in the development of the true goiter only three groups are primarily involvedriz.: (1) normal glands, (2) hyperplasias, and (3) colloid glands. The variety of secondary and complicating changes, as atrophy, degeneration, regeneration, cyst formation, etc., is almost infinite. Of the three great groups, normal glands are the most important to have firmly established, since they form the base to which all other changes must be referred for comparison.

Active hyperplasias comprise a gradation from the nearly normal or colloid gland (true hypertrophy) to the extreme degrees of hyperplasia seen in exophthalmic goiter. The histological appearance of a given specimen, apart from the degree of hyperplasia and whatever secondary changes may be present, is modified by two important factors-viz: (1) the number of times the gland has returned to the colloid state (reversion), as, for example, in the case of repeated pregnancies when during each pregnancy there was active hyperplasia and during each interval there was a return to the colloid state; and (2) the length of time active hyperplasia has continued without a period of rest. Thus, in the marked hyperplasias of exophthalmic goiter or of cretins, ${ }^{36}$ we see apparent over-

33. Schöne: Virchow's Arch. f. path. Anat., 1909, cxcv, 169.

34. Wölfler: Arch. f. klin. Chir., 1883, xxix, i, 754.

35. Bradley: Jour. Exper. Med., 1896, i, 401.

36. McGarrison: Proc. Roy. Soc. Med., 1908, ii, No. 3, Med. Section, p. 1. 
growth of fibrous tissue with very striking irregularities and disturbances in the nucleus-plasma relations of epithelial cells. These nucleus-plasma disturbances in cretin dogs are able to right themselves when iodin is administered, and in such glands one may then produce a regular, uniform, compensatory hyperplasia by partial removal. Colloid glands are but exaggerations of all the structures of normal glands, depending on the degree of active hyperplasia preceding the involution (reversion). It is our belief that all colloid glands have been preceded by active hyperplasia, and that passive dilatation of the alveoli due to continued secretory activity and obstruction to the lymphatic drainage is of secondary importance. Rupture of the alveoli and other secondary and complicating changes may occur. So also a colloid gland may undergo secondary active hyperplasia differing essentially in no way from the primary form occurring in a normal gland.

RELATION OF SEX AND AGE OF THE ANIMAL AND SIZE OF THE GLAND TO HISTOLOGIC STRUCTURE

It is usually stated by anatomists that the normal human thyroid is larger in infants and children and in females than in later periods of life or in males-i. e., larger in relation to the body weight. Other than this, sex and age have no particular relation to normal glands. The normal gland at birth is well differentiated into colloid-containing vesicles in the sheep, dog, ox and man. As a class normal glands are the smallest met. The average weights in our series were $2.08 \mathrm{gm}$. for dogs, $12 \mathrm{gm}$. for oxen, $6.9 \mathrm{gm}$. for sheep, and $24 \mathrm{gm}$. for man. ${ }^{37}$

Active hyperplasias in man are definitely associated with age and sex. Sex has no important relation to the hyperplasias in the dog, ox, sheep and pig. In man also sex is not a modifying factor in the hyperplasias of infancy and childhood. Starting with puberty, however, active hyperplasia is more common in females. The clinical incidence is variously estimated $^{38}$ from 3 to 1 to 6 to 1 . The actual or anatomical incidence in our series is modified by the larger proportion of males in the autopsy material and the larger proportion of females in the surgical material; and also by the fact that any thyroids showing anatomical complications were not used. These factors make deductions worthless. The metabolic disturbances associated with the establishment of menstrual functions, with menstruation, with pregnancy and lactation, and with the meno-

37. Wondenberg (Virchow's Arch, f. path. Anat., 1909, cxevi, 107) has reported much higher weights for normal glands in these animals.

38. Dock: Osler's Modern Medicine, 1909, vi, 404. 
pause are particularly associated with goiter development. Nothing is known definitely regarding the physiological nature of the disturbances which stimulate the thyroid to hyperplasia at these particular periods.

Age is a factor in the hyperplasias common to all animals. They are more frequently observed in the young, when the thyroid is normally Iunctionally more active. This is particularly true of the lower animals. In man it is also true, but there are modifying factors not sufficiently prominent in the lower animals, as, for example, the sexual cycle and the disturbances leading to exophthalmic goiter, which are particularly asscciated with goiter formation, and which modify the age limitations of human goiter.

As regards the size of the glands, it may be stated that the size varies with the degree of hyperplasia. There are exceptions to this rule, especially in man. These exceptions most likely depend on a more complicated etiology and life cycle in human goiters.

Colloid glands of the lower animals have no noteworthy relation to sex. Sex is also not a factor in human colloid glands before puberty. After puberty colloid glands are more common in females, for the reason that hyperplasias are more common.

Age is a very important factor in colloid glands of all animals. They are always sequels of active hyperplasia and therefore occur at correspondingly later periods of life. The size of the colloid gland depends mainly on the degree of hyperplasia preceding the involution (reversion). Other factors, as repeated hyperplasia, medication and lymphatic obstruction inducing passive dilatation of the vesicles, operate, to a less extent, to modify the size. Thus colloid glands may be no larger than normal glands, or they may attain the size of the largest goiters.

Summing up, it is seen that age and sex bear no important relation to normal glands. In the hyperplasias age is of great importance, while sex is an important factor only in those hyperplasias in man occurring during and after puberty. In colloid glands age is also a very important factor in all animals-while sex is important in the human forms occurring during and after puberty.

As regards size, normal glands as a class are the smallest observed. In the hyperplasias the size depends on the degree of hyperplasia and in colloid glands the size as a rule depends on the degree of the preceding hyperplasia. Thus, while the size of the gland, the age and the sex of the animal are related to the gland structure and its variations, they can be considered as only secondary and accompanying factors to the fundamental causes in the etiology of goiter. 


\section{IODIN DETERMINATION}

Iodin determinations have been made on 161 different human thyroids, of which 96 are used in the following 14 tables, where they have been classified according to their histology. The method used in determining the iodin content is fully described in an earlier publication (Marine and Williams ${ }^{4}$ ) and has been used throughout without modification. We have used several modifications of the method proposed from time to time, but all our observations by means of these modifications and of controls in thirty-one cases have convinced us that the above method will not lead to erroneous conclusions if only the iodin content in relationship with the histological structures is considered. The method and the proposed modifications are not quantitatively accurate.

The three natural anatomical groups--viz: (1) normal thyroids, (2) colloid thyroids, and (3) actively hyperplastic thyroids, with the arbitrary subdivision of the latter group-are also the same as those previously used and described.

The anatomical standards being the same or as nearly the same as it was possible to make them, we have also brought forward the iodin determinations in dog, sheep, pig and ox thyroids for comparison.

One important addition to the earlier recorded observations will be noted in that the human colloid series is nearly complete and the canine colloid series is sufficiently complete to parallel the normal series in these two animals and will be discussed with equal emphasis.

The reasons-anatomical, chemical (iodin) and biological--for establishing a colloid series parallel with the normal series have already been set forth at some length (Marine and Lenhart ${ }^{2}$ ) and need not be reviewed here except to state that the only essential difference between normal and colloid glands is that colloid glands have at some time undergone active hyperplasia, while strictly normal glands have never undergone such hyperplasia.

As above stated, 161 different human thyroids have been analyzed fo: iodin, of which 111 were autopsy specimens and 50 surgical specimens. Of these only 96 , of which $7 \%$ were autopsy specimens and 19 surgical specimens, have been included in the tables of analysis. Of the $34(30.6$ per cent.) autopsy specimens not used $\mathbf{1 1}$ were from children under two years; 10 from old subjects showing histologically marked senile atrophy; 2 contained multiple small fetal adenomata; 3 showed marked atrophy with fibrosis associated with chronic pulmonary tuberculosis; 6 had, to our knowledge, been fed large amounts of iodin-containing compounds during the last few months of life; 1 showed marked simple atrophy without assignable cause (myxedema), and 1 specimen had been handled 
for demonstration purposes. Of the 31 (62 per cent.) surgical specimens not used, 11 had been previously treated with iodin containing compounds; 14 were discarded on account of old hemorrhagic-cysticdegenerative changes; 5 were discarded on account of fetal adenomata, and 1 for malignant tumor (endothelioma).

The fact that 65 ( 40.4 per cent.) could not, for one or another reason above mentioned, be included in the tables clearly shows that no conclusions can be drawn from a limited material even if this material be from autopsies with no clinical suspicion of thyroid disease. With surgical material this is especially true. Our percentage (38 per cent.) of uncomplicated surgical specimens is unusually high and is due to the presence of several uncomplicated cases of exophthalmic goiter. We have pointed this out specifically here because in all publications thus far recorded on the relation of iodin to human goiter the complicating factor's have not been taken into account. We also feel certain that a larger scries than we have here recorded, whether autopsy or surgical, would modify the figures here given, particularly if the district from whence the glands were taken were goitrous, while, on the other hand, a smaller scries would give more uniform results if seacoast glands were used.

Pure types of histological changes only can be used, because, in the present state of our knowledge, we can not discount for the multiple anatomical complicating factors so common in the thyroid and which have already been alluded to.

Then, too, besides the anatomical complications, there are a great group of metabolic (physiological) changes producing effects on the structure or secretion of the gland either too slight or too temporary to be accurately asceltained or discounted. We refer to such conditions as variations depending on the seasons of the year, ${ }^{39}$ on the sexual functions, on rest, on menstruation, on pregnancy, on climatic variations, ${ }^{40}$ on food variations, etc.

Thus by eliminating all known untoward factors there are still present many uncertainties which can not be avoided at present and render conclusions from such data dangerous except those on the general relation of iodin with the structure and physiology of the thyroid.

The individual cases of the normal and colloid human series have been tabulated separately (Tables 15 and 16). It will be noticed that in only a few cases is the jodin content calculated for the fresh gland. This is due to the fact that the other specimens had been preserved in 10 per cent. formalin from one to seven days before being used. This factor, as

39. Koch, F. C.: Discussion on Hunt and Seidell's paper on commercial preparations. Jour. Am. Med. Assn., 1908, li, 1389.

40. Sawyer, J. P.: New York Med. Jour., 1907, Ixxxvi, 68. 
Williams ${ }^{41}$ has shown, makes little or no difference as regards the iodin content per gm. of dried gland.

It was impossible to get actual weights of the thyroids in the fresh condition in most instances and we have only indicated roughly their size by the terms "normal," "slightly enlarged," "moderately enlarged" and "markedly enlarged." Thus thyroids from adults weighing between 20-30 gm. we have called "normal," between 30 and 50 "slightly enlarged," between 50 and 100 "moderately enlarged," and over $100 \mathrm{gm}$. "markedly enlarged."

Since the iodin content in relationship with the individual anatomical groupings has been discussed at length in earlier publications, they will here be discussed collectively in relationship with the basic anatomical groups-normals, colloids and the two series of hyperplasias.

\section{NORMAL GLANDS *}

Normal glands have the highest mean and average iodin content per gram. This is true for all animals thus far examined. In our twentythree human specimens the highest iodin content per gram of dried gland was $3,691 \mathrm{mgm}$; the lowest $1,30 \% \mathrm{mgm}$. The significance and explanation of this great variation in histologically normal glands becomes of greater importance when one notes that it is also seen with the dog, sheep, ox and pig thyroids. Whether it indicates variations in the intake or variations in the consumption within the organism, or both, is not clear. The evidence at present available indicates that the consumption of iodized protein in the body is the most constant. Thus it is known that the administration of very small amounts of iodin is followed by its rapid storage in the gland in all animals, the rapidity of the process depending on the degree of hyperplasia (therefore, on the lack of iodin). On the other hand, it is known that the withholding of iodin, as by a fresh meat diet, ${ }^{42}$ causes a slow loss of iodin from the gland. That these variations (1.30\%-3.691 $\mathrm{mgm}$.) are not due to accumulation of iodin, either by accident or to an effort to render inert the piosonous properties of iodin, is both true and false. Thus there are differences that depend purely on the accidental content of the food in iodin. It is also probably true that the iodin, so long as it remains in the thyroid, is inert (to the host), because it represents merely the stored iodin, or the factor of safety. On the other hand, broadly interpreted, none of the iodin in the thyroid is inert or accidental, inasmuch as it is stored there for the

41. Marine, D., and Williams, W. W.: The relation of iodin to the structure of the thyroid gland. The Archives INT. Med., 1908, $i, 378$.

* See Tables 1 and 15.

42. Baumann: München. med. Wehnschr., 1896, xliii, 309. 
purpose of later becoming available to the organism. All observers, from whatever angle they approach the question, have concluded that the iodin content determined the physiological activity of the protein (thyreoglobulin). Thus Roos ${ }^{43}$ observed that the increased nitrogen excretion induced by feeding thyreoglobulin depended on its iodin content. Hunt ${ }^{44}$ has found that the protection offered to mice against acetonitrile poisoning depends on the iodin content. We have shown the biological fact that if the iodin falls below a quite constant level the gland undergoes characteristic and constant histologic changes, while, if iodin is given, these changes either do not occur or, if they have started, they are arrested. As one of $\mathrm{us}^{45}$ has previously indicated, we believe that the organism retains iodin in the same way that it retains iron and calcium, etc., and that the difference between the greatest amount of either iodin, iron or calcium and the least amount that may be found in the animal to be compatible with the maintenance of normal histological structure of the tissues immediately concerned with their storage and elaboration, represents the excess of intake over consumption, or the true physiological factor of safety. ${ }^{46}$

\section{NORMAL SERIES-VARIOUS ANIMALS}

TABLE 1.- Normal Glands *

\begin{tabular}{|c|c|c|c|c|c|c|c|}
\hline Animal. & $\begin{array}{c}\text { No. } \\
\text { Cases. }\end{array}$ & E. Iodin & $\begin{array}{c}\text { Per Gm., } \\
\text { N. }\end{array}$ & Dried.- & E. Iodin & $\begin{array}{c}\text { Per Gm., } \\
\text { M. }\end{array}$ & Fresh. \\
\hline Sheep $\ldots$. & 19 & $\begin{array}{l}4.614 \\
1.247\end{array}$ & 2.288 & 2.467 & $\begin{array}{l}1.318 \\
0.318\end{array}$ & 0.694 & 0.686 \\
\hline $\operatorname{Dog} \ldots \ldots$ & 3 & $\begin{array}{l}4.722 \\
1.990\end{array}$ & 3.205 & 3.322 & $\begin{array}{l}1.064 \\
0.512\end{array}$ & 0.757 & 0.777 \\
\hline Pig $\ldots \ldots$ & 18 & $\begin{array}{l}4.158 \\
1.538\end{array}$ & 2.412 & 2.515 & $\begin{array}{l}1.456 \\
0.425\end{array}$ & 0.778 & 0.884 \\
\hline $0 \times \ldots \ldots$ & 17 & $\begin{array}{l}4.768 \\
2.730\end{array}$ & 3.254 & 3.461 & $\begin{array}{l}1.592 \\
0.892\end{array}$ & 1.069 & 1.117 \\
\hline $\operatorname{Man} \ldots \ldots$ & 23 & $\begin{array}{l}3.691 \\
1.307\end{array}$ & 2.153 & 2.171 & $\begin{array}{l}0.451 \\
0.310\end{array}$ & 0.403 & 0.402 \\
\hline
\end{tabular}

* In this and the following tables, $\mathbf{E}$ stands for extreme, $\mathbf{M}$ for mean, and $\mathbf{A}$ for average. Iodin figures are in $\mathrm{mgm}$.

43. Roos: Ztschr. f. physiol. Chem., 1899, xxviii, 40.

44. Hunt: The relation of iodin to the thyroid gland. Jour. Am. Med. Assn., 1907, xlix, 1323.

45. Johns Hopkins Hosp. Bull., 1907, xviii, 359.

46. Meltzer, S. J.: The Harvey Lectures, 1906-07. Lippincott, Philadelphia, 1908, p. 139. 


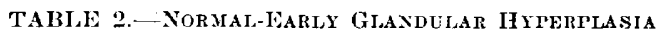

\begin{tabular}{|c|c|c|c|c|c|c|c|}
\hline Animal. & $\begin{array}{c}\text { No. } \\
\text { Cases. }\end{array}$ & $\bar{F}_{\text {F. }}$ Iodin & $\begin{array}{c}\text { Per Gim., } \\
\text { M. }\end{array}$ & Dried. & $\begin{array}{l}\text {.-Iodin } \\
\text { E. }\end{array}$ & $\begin{array}{c}\text { Pel Gm. } \\
\mathbf{M}\end{array}$ & $\begin{array}{c}\text { Fresh.-- } \\
\mathbf{A} .\end{array}$ \\
\hline \multirow[t]{2}{*}{ Sheep } & \multirow[t]{2}{*}{1} & $\cdots \cdots$ & \multirow[t]{2}{*}{$\cdots \cdots$} & \multirow[t]{2}{*}{0.677} & $\cdots$ & \multirow[t]{2}{*}{$\cdots \cdots$} & \multirow[t]{2}{*}{0.176} \\
\hline & & $\cdots \cdots$ & & & $\cdots \cdots$ & & \\
\hline \multirow{2}{*}{ Dog } & \multirow{2}{*}{7} & 1.296 & \multirow{2}{*}{0.81 .5} & \multirow{2}{*}{0.879} & & \multirow{2}{*}{0.153} & \multirow{2}{*}{0.174} \\
\hline & & 0.483 & & & 0.018 & & \\
\hline \multirow[t]{2}{*}{ lig } & \multirow[t]{2}{*}{1} & & \multirow[t]{2}{*}{$\ldots \ldots$} & \multirow[t]{2}{*}{1.230} & & \multirow[t]{2}{*}{$\cdots$} & \multirow[t]{2}{*}{0.337} \\
\hline & & $\cdots \cdots$ & & & $\cdots \cdots$ & & \\
\hline \multirow{2}{*}{$O x$} & \multirow{2}{*}{7} & 2.676 & \multirow{2}{*}{2.307} & \multirow{2}{*}{2.317} & 0.726 & \multirow{2}{*}{0.653} & \multirow{2}{*}{0.628} \\
\hline & & 2.000 & & & 0.482 & & \\
\hline \multirow{2}{*}{ Man } & \multirow[b]{2}{*}{4} & 0.984 & \multirow{2}{*}{0.807} & \multirow{2}{*}{0.803} & 0.216 & & \multirow{2}{*}{0.206} \\
\hline & & 0.615 & & & 0.196 & & \\
\hline
\end{tabular}

TABLE 3.-Earily Giandelar Hyperplasia

\begin{tabular}{|c|c|c|c|c|c|c|c|}
\hline Animal. & $\begin{array}{c}\text { No. } \\
\text { Cases. }\end{array}$ & ${ }_{\text {E. }}$ Iodin & $\begin{array}{c}\text { Per Gm., } \\
\mathbf{M} .\end{array}$ & Dried..- & F. & $\begin{array}{c}\text { Per Gm., } \\
\mathbf{M} .\end{array}$ & $\begin{array}{c}\text { Fresh. - - } \\
\text { A. }\end{array}$ \\
\hline Sheep . . . & . & $\begin{array}{l}\cdots \\
\ldots\end{array}$ & $\cdots \cdots$ & $\cdots \cdots$ & $\begin{array}{l}\cdots \cdots \\
\ldots \ldots\end{array}$ & $\cdots \cdots$ & $\cdots \cdots$ \\
\hline$\ldots \ldots$ & 9 & $\begin{array}{l}1.008 \\
0.243\end{array}$ & 0.654 & $0.62 \overline{5}$ & $\begin{array}{l}0.23 \overline{5} \\
0.063\end{array}$ & 0.113 & 0.139 \\
\hline Pig $\ldots \ldots$ & 2 & $\begin{array}{l}1.158 \\
1.046\end{array}$ & $\cdots \cdots$ & 1.102 & $\begin{array}{l}0.291 \\
0.279\end{array}$ & $\cdots \cdots$ & 0.285 \\
\hline$\ldots \ldots$ & 3 & $\begin{array}{l}-2.186 \\
1.123\end{array}$ & 1.630 & 1.646 & $\begin{array}{l}0.615 \\
0.314\end{array}$ & 0.456 & 0.462 \\
\hline $\operatorname{Man} \ldots \ldots$ & $\pi$ & $\begin{array}{l}1.0 \overrightarrow{7} \\
0.738\end{array}$ & 0.877 & 0.895 & $\begin{array}{l}\cdots \\
\ldots \\
\cdots\end{array}$ & $\ldots$ & \\
\hline
\end{tabular}

Tabie 4.-Early-Moderate Glaxdriar II perpuasia

\begin{tabular}{|c|c|c|c|c|c|c|c|}
\hline Animal. & $\begin{array}{c}\text { No. } \\
\text { Cases. }\end{array}$ & $\overline{\text { E. }}^{\text {lodin }}$ & $\begin{array}{c}\text { Per Gm., } \\
\mathbf{M} .\end{array}$ & $\begin{array}{r}\text { Dried.- } \\
\mathbf{A} .\end{array}$ & F. Iodin & $\begin{array}{c}\text { Per Gm., } \\
\text { M. }\end{array}$ & $\begin{array}{c}\text { Fresh.- } \\
A .\end{array}$ \\
\hline Sheep ... & 1 & $\cdots$ & $\ldots$ & 0.548 & $\begin{array}{l}\cdots \cdots \\
\ldots\end{array}$ & $\cdots \cdots$ & 0.131 \\
\hline Dog $\ldots \ldots$ & 1 & $\cdots$ & $\cdots \cdots$ & 0.262 & $\begin{array}{l}\cdots \\
\ldots\end{array}$ & $\ldots$ & 0.082 \\
\hline Pig $\ldots \ldots$ & 3 & $\begin{array}{l}0.846 \\
0.769\end{array}$ & 0.769 & 0.795 & $\begin{array}{l}0.241 \\
0.198\end{array}$ & 0.233 & 0.224 \\
\hline$\ldots \ldots$ & 5 & $\begin{array}{l}1.030 \\
0.969\end{array}$ & 1.000 & 1.000 & $\begin{array}{l}0.252 \\
0.205\end{array}$ & 0.222 & 0.226 \\
\hline $\operatorname{Man} \ldots .$. & 3 & $\begin{array}{l}0.738 \\
0.406\end{array}$ & 0.554 & 0.566 & $\cdots \cdots$ & $\cdots \cdots$ & \\
\hline
\end{tabular}


TABLE 5.-Moderate Giandilar Hyperpiasia

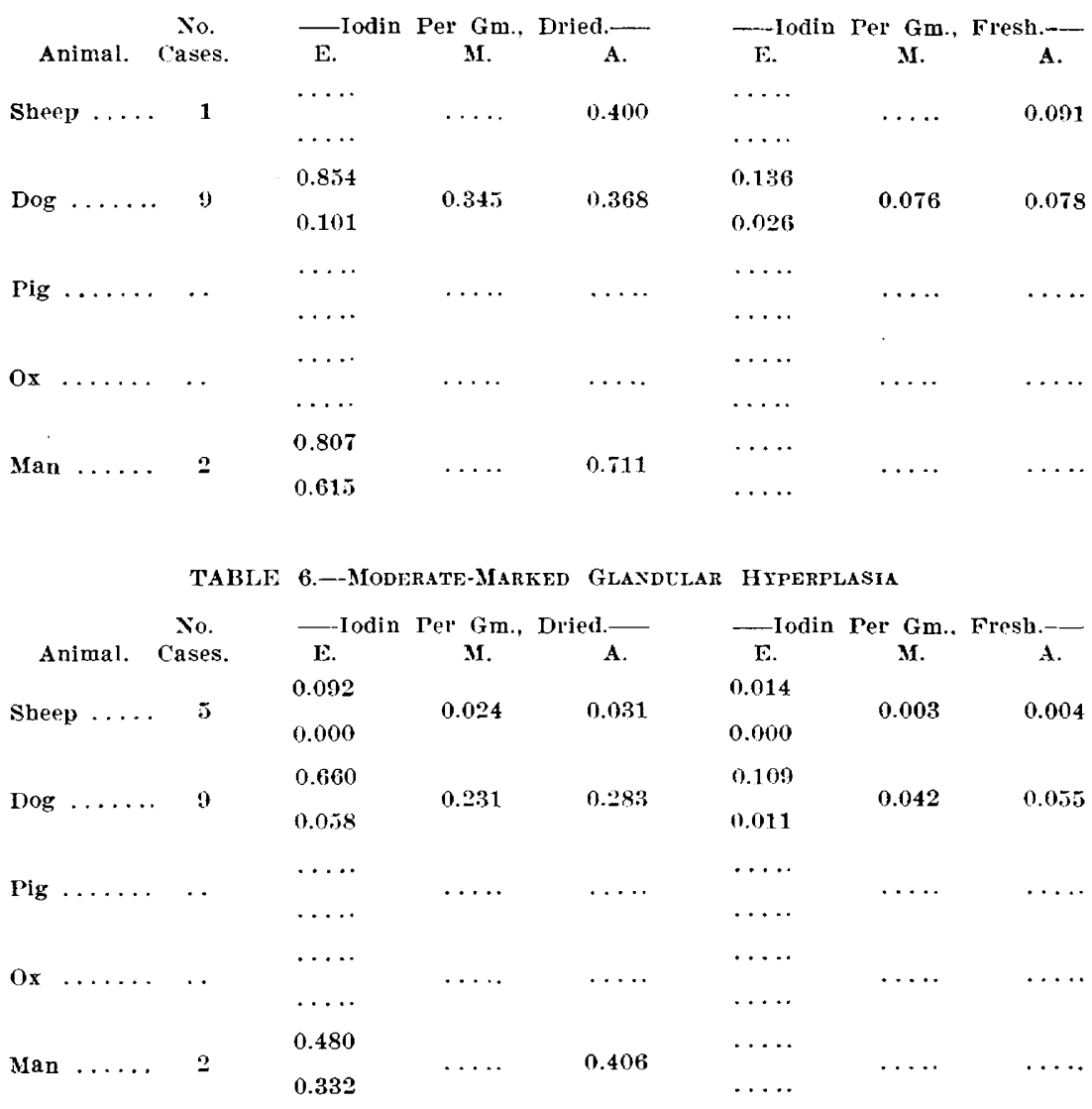

TABLE 7.-MaRked Gianditar Hyperpiasia

\begin{tabular}{|c|c|c|c|c|c|c|c|}
\hline Animal. & $\begin{array}{c}\text { No. } \\
\text { Cases. }\end{array}$ & Is. & $\begin{array}{c}\text { Pel Gm., } \\
\text { M. }\end{array}$ & Dried.- & E. & $\begin{array}{c}\text { Per Gm., } \\
\mathbf{M} .\end{array}$ & $\begin{array}{c}\text { Fresh.-- } \\
\text { A. }\end{array}$ \\
\hline Sheep & 6 & $\begin{array}{l}0.036 \\
0.000\end{array}$ & 0.000 & 0.006 & $\begin{array}{l}0.006 \\
0.000\end{array}$ & 0.000 & 0.001 \\
\hline Dog $\ldots \ldots$ & 18 & $\begin{array}{l}0.640 \\
0.008\end{array}$ & 0.073 & 0.114 & $\begin{array}{l}0.123 \\
0.002\end{array}$ & 0.014 & 0.023 \\
\hline Pig $\ldots \ldots$ & $\cdots$ & $\begin{array}{l}\ldots \\
\ldots \\
\cdots\end{array}$ & $\cdots \cdots$ & $\cdots$ & $\begin{array}{l}\cdots \\
\cdots\end{array}$ & $\cdots \cdots$ & $\ldots$ \\
\hline$\cdots \cdots$ & 5 & $\begin{array}{l}0.270 \\
0.077\end{array}$ & 0.215 & 0.189 & $\begin{array}{l}0.062 \\
0.016\end{array}$ & 0.042 & 0.041 \\
\hline $\operatorname{Man} \ldots \ldots$ & 7 & $\begin{array}{l}0.584 \\
0.118\end{array}$ & 0.292 & 0.323 & $\begin{array}{l}0.11 \overline{5} \\
0.060\end{array}$ & 0.109 & 0.095 \\
\hline
\end{tabular}


COLLOID SERIES-VARIOUS ANIMALS

TABLE 8.-COLroid Glands

\begin{tabular}{|c|c|c|c|c|c|c|c|}
\hline Animal. & $\begin{array}{l}\text { No. } \\
\text { Cases. }\end{array}$ & $\overline{\mathrm{E}}^{\text {Iodin }}$ & $\begin{array}{c}\text { Per Gm., } \\
\text { M. }\end{array}$ & Dried.- & $\bar{E}^{\text {Iodin }}$ & $\begin{array}{c}\text { Per Gm., } \\
\text { M. }\end{array}$ & Fresh.- \\
\hline Sheep .... & 3 & $\begin{array}{l}3.691 \\
1.769\end{array}$ & 3.529 & 2.996 & $\begin{array}{l}1.027 \\
0.455\end{array}$ & 0.974 & 0.818 \\
\hline $\operatorname{Dog} \ldots \ldots$ & 8 & $\begin{array}{l}3.608 \\
0.846\end{array}$ & 1.816 & 1.985 & $\begin{array}{l}1.039 \\
0.132\end{array}$ & 0.406 & 0.459 \\
\hline Pig ...... & 2 & $\begin{array}{l}2.768 \\
1.938\end{array}$ & $\cdots \cdots$ & 2.353 & $\begin{array}{l}0.805 \\
0.557\end{array}$ & & 0.681 \\
\hline$o x \ldots \ldots$ & . & $\begin{array}{c}\cdots \\
\cdots\end{array}$ & $\ldots \ldots$ & $\cdots \cdots$ & $\cdots$ & $\ldots$. & $\cdots \cdots$ \\
\hline $\operatorname{Man} \ldots \ldots$ & 25 & $\begin{array}{l}3.914 \\
0.784\end{array}$ & 1.769 & 1.996 & $\begin{array}{l}0.798 \\
0.304\end{array}$ & 0.479 & 0.515 \\
\hline
\end{tabular}

TABLE 9.-Colloid-Early Glandllar Hyperplasia

\begin{tabular}{|c|c|c|c|c|c|c|c|}
\hline Animal. & $\begin{array}{c}\text { No. } \\
\text { Cases. }\end{array}$ & $\overline{\mathrm{E}}^{\text {Iodin }}$ & $\begin{array}{c}\text { Per Gm., } \\
\text { M. }\end{array}$ & Dried.- & E. & $\begin{array}{c}\text { Per Gm., } \\
\text { M. }\end{array}$ & $\begin{array}{c}\text { Fresh. } \\
\text { A. }\end{array}$ \\
\hline Sheep .... & 4 & $\begin{array}{l}1.000 \\
0.461\end{array}$ & 0.853 & 0.792 & $\begin{array}{l}0.282 \\
0.138\end{array}$ & 0.201 & 0.206 \\
\hline Dog ....... & 6 & $\begin{array}{l}1.443 \\
0.431\end{array}$ & 0.953 & 0.945 & $\begin{array}{l}0.302 \\
0.125\end{array}$ & 0.221 & 0.217 \\
\hline Pig $\ldots \ldots$ & $\cdots$ & $\begin{array}{l}\cdots \cdot \\
\cdots \cdots\end{array}$ & $\cdots \cdots$ & $\cdots \cdots$ & $\begin{array}{l}\cdots \\
\cdots\end{array}$ & $\ldots$ & $\cdots \cdots$ \\
\hline ox $\ldots \ldots \ldots$ & $\cdots$ & $\begin{array}{l}\cdots \cdots \\
\ldots \ldots\end{array}$ & $\cdots \cdots$ & $\cdots$ & $\begin{array}{l}\cdots \\
\cdots \\
\cdots\end{array}$ & $\cdots \cdots$ & $\cdots \cdots$ \\
\hline Man ..... & 8 & $\begin{array}{l}0.887 \\
0.461\end{array}$ & 0.823 & 0.777 & $\cdots$ & $\ldots \cdots$ & 0.208 \\
\hline
\end{tabular}

TABLE 10.-Colloid-Early-Moderate Glandurar Hyperplasia

\begin{tabular}{cccccc} 
No. & Elodin Per Gm., Dried.- & & \multicolumn{2}{c}{ Iodin Per Gm., Fresh.-_ } \\
Animal. Cases. & E. & M. & A. & & E.
\end{tabular}

\begin{tabular}{|c|c|c|c|c|c|c|c|}
\hline sheep ..... & . & $\cdots \cdots$ & $\cdots$ & $\ldots \ldots$ & $\begin{array}{l}\cdots \\
\ldots \\
\cdots\end{array}$ & $\cdots$ & $\ldots$. \\
\hline & & 0.692 & & & 0.167 & & \\
\hline $\operatorname{Dog} \ldots \ldots \ldots$ & 2 & 0.560 & $\ldots$. & 0.626 & 0.114 & $\ldots \ldots$ & 0.140 \\
\hline Pig $\ldots . .$. & . & $\begin{array}{c}\cdots \cdots \\
\cdots \cdots\end{array}$ & $\cdots \cdots$ & $\cdots \cdots$ & $\begin{array}{l}\cdots \cdots \\
\cdots\end{array}$ & $\cdots$ & $\cdots \cdot$ \\
\hline ox $\ldots \ldots$ & . & $\begin{array}{l}\cdots \\
\cdots \\
\cdots\end{array}$ & $\ldots \ldots$ & $\ldots$ & $\begin{array}{l}\cdots \\
\cdots\end{array}$ & $\ldots$ & $\ldots$ \\
\hline $\operatorname{Man} \ldots \ldots$ & 2 & $\begin{array}{l}0.600 \\
0.446\end{array}$ & $\cdots \cdots$ & 0.523 & $\cdots$ & $\cdots$ & \\
\hline
\end{tabular}


TABLE 11.-Collotd-Moderate Grandular hrperplasia

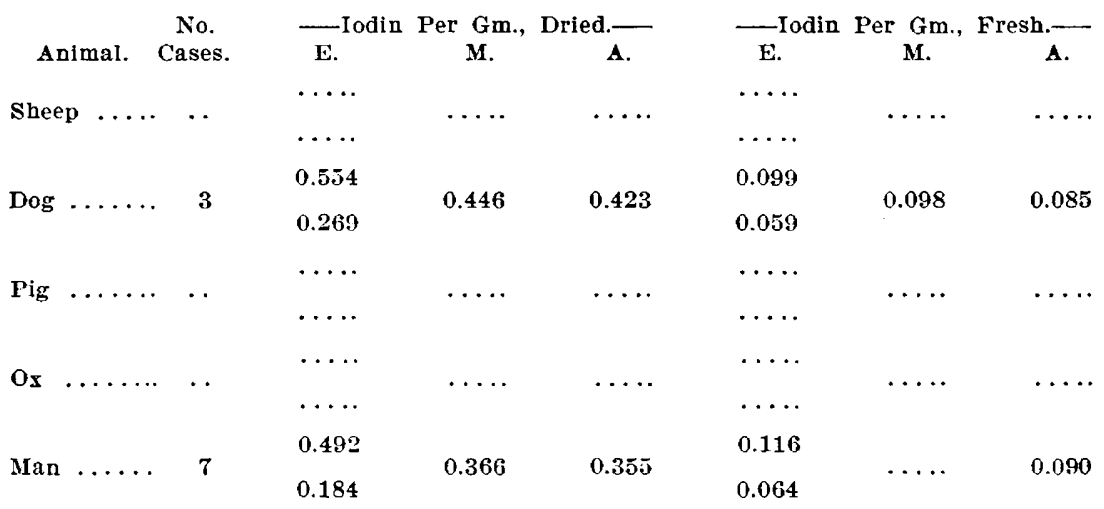

TABLE 12.-Colloid-Moderate-Marked Glandular Hyperplasia

\begin{tabular}{|c|c|c|c|c|c|c|c|}
\hline & No. & 一Iodin & Per Gm., & Dried.ـــ & - Iodin & Per Gm., & Fresh.- \\
\hline Animal. & Cases. & E. & M. & A. & E. & M. & A. \\
\hline Sheep .... & $\cdots$ & $\begin{array}{c}\ldots \\
\ldots \\
\cdots\end{array}$ & $\cdots \cdots$ & $\cdots \cdots$ & $\begin{array}{l}\ldots \\
\ldots\end{array}$ & $\ldots$ & $\ldots$ \\
\hline $\operatorname{Dog} \ldots \ldots$ & 1 & $\begin{array}{l}\ldots \\
\ldots\end{array}$ & $\cdots \cdots$ & 0.128 & $\begin{array}{l}\ldots \\
\ldots \\
\ldots\end{array}$ & $\cdots \cdots$ & 0.030 \\
\hline Pig $\ldots \ldots$ & . & $\begin{array}{l}\ldots \ldots \\
\ldots\end{array}$ & $\ldots$ & $\cdots \cdots$ & $\begin{array}{c}\cdots \\
\cdots\end{array}$ & $\cdots \cdots$ & $\cdots \cdots$ \\
\hline $\mathrm{ox}_{\mathrm{x}} \ldots \ldots$ & . & $\begin{array}{l}\ldots \\
\cdots\end{array}$ & $\ldots$ & $\cdots \cdots$ & $\begin{array}{l}\ldots \\
\ldots\end{array}$ & $\ldots$ & $\cdots \cdots$ \\
\hline $\operatorname{Man} \ldots \ldots$ & . & $\cdots$ & $\ldots$ & $\cdots \cdots$ & $\ldots$ & $\cdots$ & $\cdots \cdots$ \\
\hline
\end{tabular}

\section{TABLE 13.-Colloid-Marked Glandular hyperplasia}

\begin{tabular}{cccccc} 
No. & Iodin Per Gm., Dried.- & & \multicolumn{2}{c}{ Iodin Per Gm., Fresh.- } \\
Animal. Cases. & E. & M. & A. & & E.
\end{tabular}

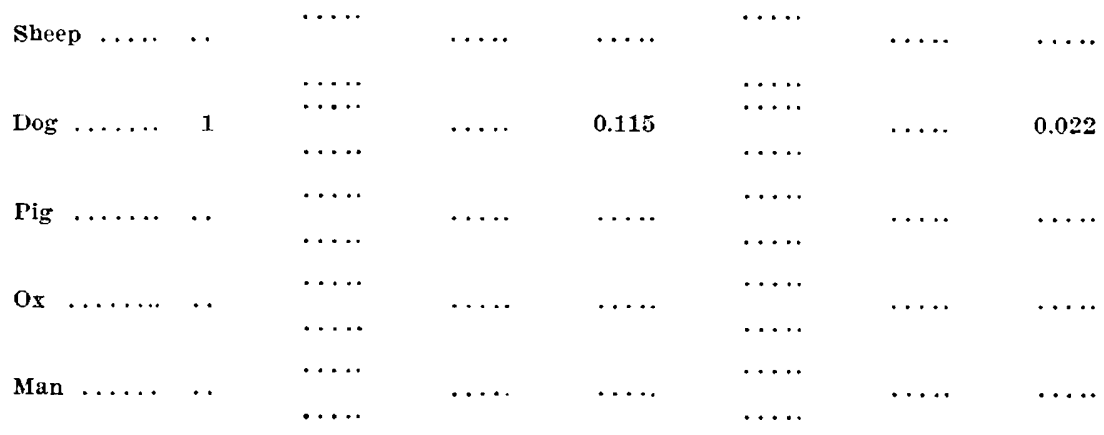




\begin{tabular}{|c|c|c|c|c|c|c|c|}
\hline & & TABLE & 14.-Nor & MAL-COLLOID & GLANDS. & & \\
\hline Animal. & $\begin{array}{c}\text { No. } \\
\text { Cases. }\end{array}$ & E. Iodin & $\begin{array}{c}\text { Per Gm., } \\
\text { M. }\end{array}$ & Dried.- & F. & $\begin{array}{c}\text { Per Gm., } \\
\text { M. }\end{array}$ & Fresh. \\
\hline Sheep .... & . & $\cdots$ & $\cdots \cdots$ & $\cdots \cdots$ & $\cdots$ & $\cdots \cdots$ & $\cdots \cdots$ \\
\hline $\operatorname{Dog} \ldots \ldots$ & $\cdots$ & $\begin{array}{l}\cdots \\
\ldots\end{array}$ & $\cdots \cdots$ & $\cdots \cdots$ & $\begin{array}{l}\ldots \ldots \\
\ldots\end{array}$ & $\cdots \cdots$ & $\cdots \cdots$ \\
\hline$\ldots \ldots$ & . & $\begin{array}{l}\cdots \\
\cdots\end{array}$ & $\cdots \cdots$ & $\cdots \cdots$ & $\begin{array}{l}\cdots \\
\ldots\end{array}$ & $\cdots \cdots$ & $\cdots \cdots$ \\
\hline$O_{x} \ldots \ldots$ & . & $\begin{array}{l}\cdots \\
\ldots\end{array}$ & $\cdots \cdots$ & $\cdots \cdots$ & $\begin{array}{l}\cdots \\
\ldots\end{array}$ & $\cdots \cdots$ & $\cdots \cdots$ \\
\hline$\ldots \ldots$ & 8 & $\begin{array}{l}3.230 \\
1.100\end{array}$ & 1.653 & 1.942 & $\begin{array}{l}\cdots \\
\cdots\end{array}$ & $\cdots$ & $\cdots$ \\
\hline
\end{tabular}

\section{HYPERPLASTIC GLANDS}

- The two series of hyperplastic glands, "normal" and "colloid," while separate and distinct anatomically, are alike chemically (iodin). That is, the iodin varies inversely with the degree of active hyperplasia. whether the hyperplasia occurs on the basis of a normal or of a colloid gland. This is illustrated very clearly in the curves (Figs. 8 and 9) of the two series. Here it is seen that the general trend of the curve is the same for all the animals examined, and also for both the normal and the colloid series. There are twenty-three cases of active hyperplasia in the normal series and seventeen cases in the colloid seris.

1. First taking up the hyperplasias of the normal series:* The most striking and perhaps the most important fact brought out is the great drop in the iodin content that occurs before histological changes are noticed. This is equally true of all the animals (see normal series: curve, Fig. 8). Reference to Table 15 shows that the lowest normal iodin content (1,30\% mgm.) is well above the highest iodin content (1.077 mgm.) of the hyperplasias. This is also true of all the ainmals. It indicates that there is a quite constant lower limit in the iodin content necessary for the maintenance of normal gland structure and if the iodin falls below this limit, hypertrophic or hyperplastic changes begin. In our normal thyroid series the lowest iodin content per gram of dried gland associated with normal structure, and the highest iodin content associated with hyperplastic changes run as follows: For man, 1.307 and $1.07 \%$; for the dog, 1.990 and 1.296 ; for the sheep, 1.247 and 0.677 ; for the ox, 2.730 and 2.676, and for the pig, 1.538 and $1.158 \mathrm{mgm}$. Just as the earliest histological variations from the normal are the most

* See Tables 1, 7 and 15. 


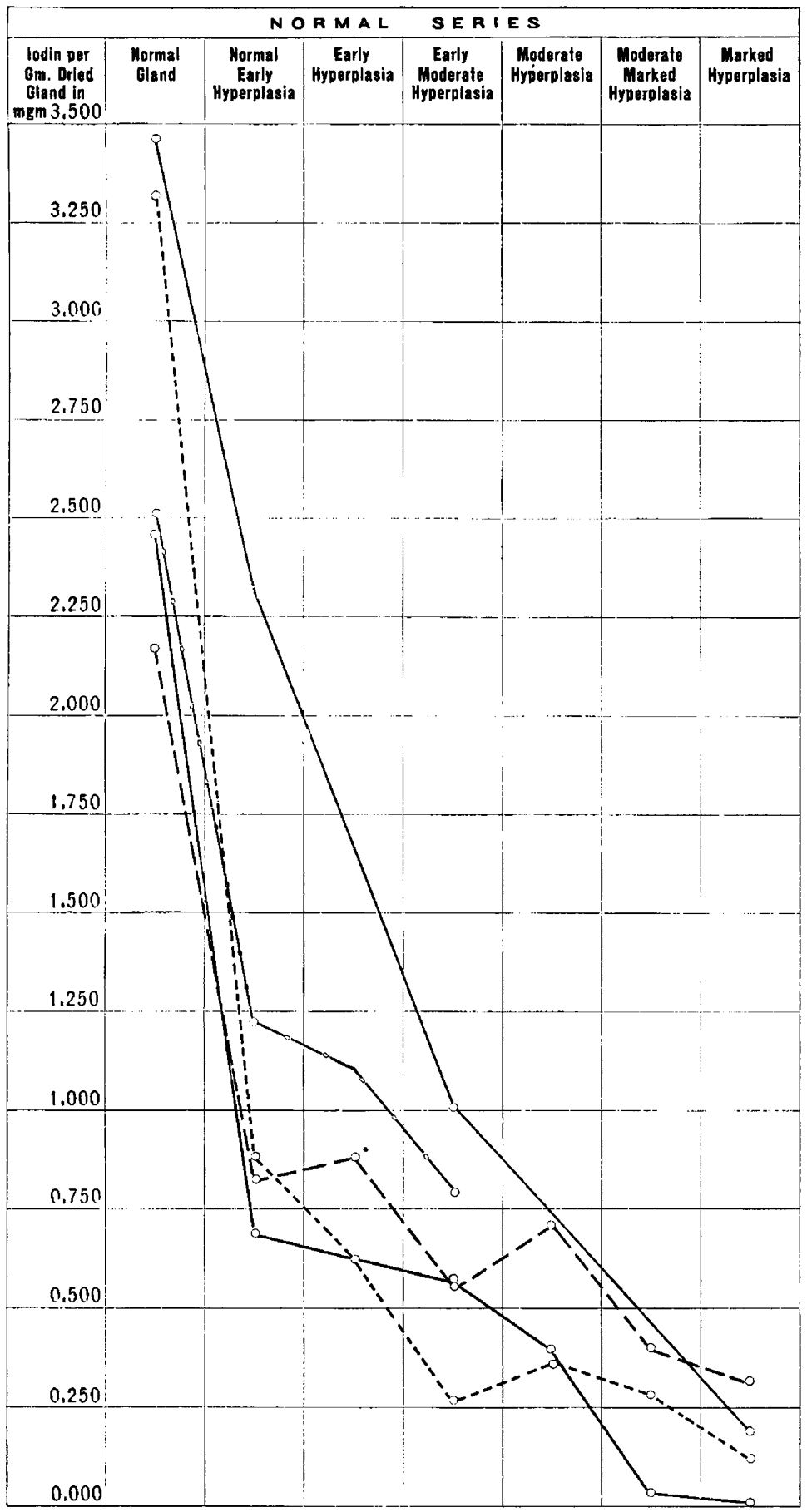

Fig. 8.-Curves compiled from the average iodin contents per gram of dried gland of the normal series of hyperplasias. The solid line represents the curve for the ox, the dotted line the curve for the dog, the line composed of short and long dashes the curve for the sheep, the line with short dashes the curve for man, and the line composed of long dashes and circles the curve for the pig. 


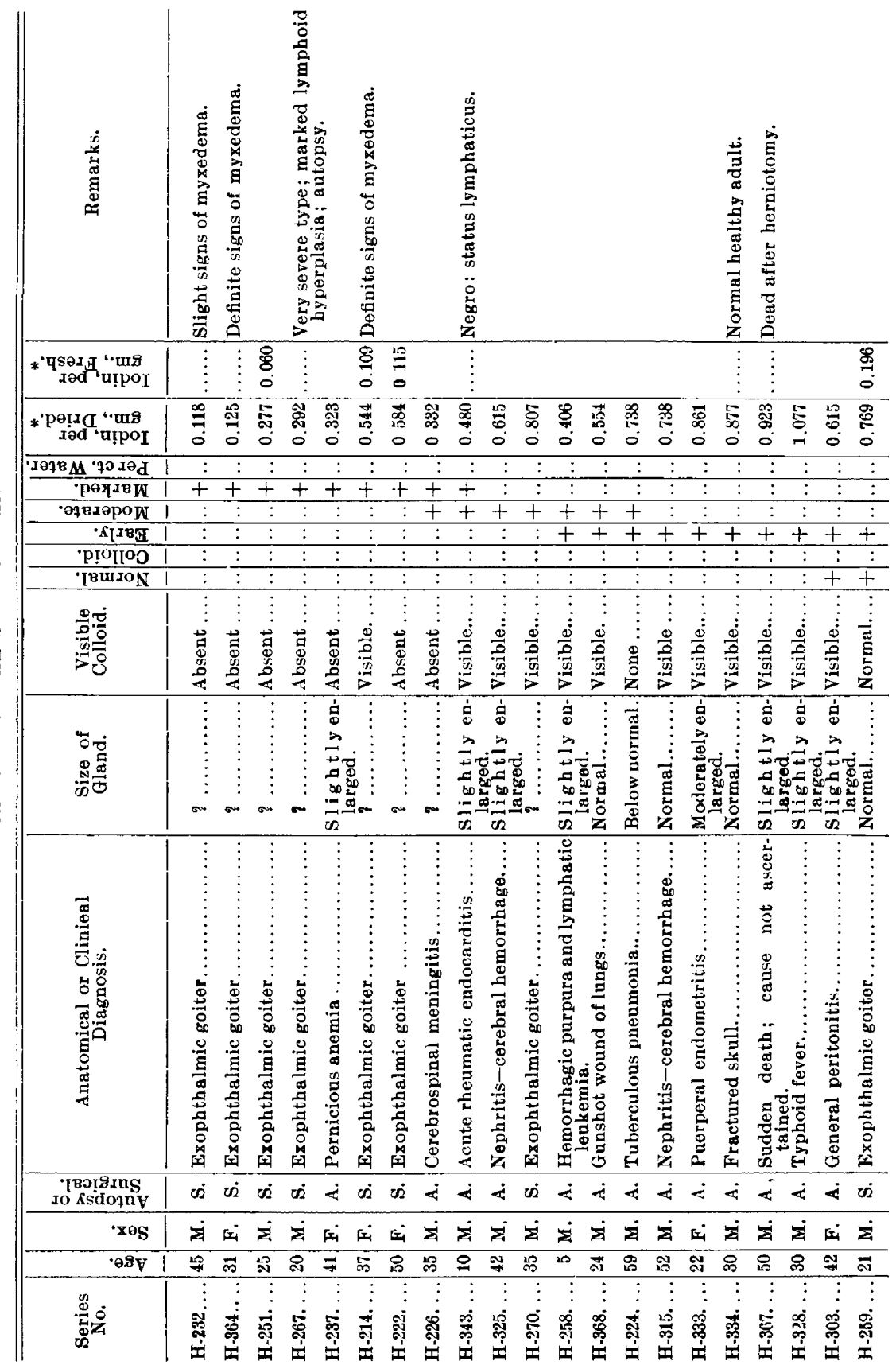




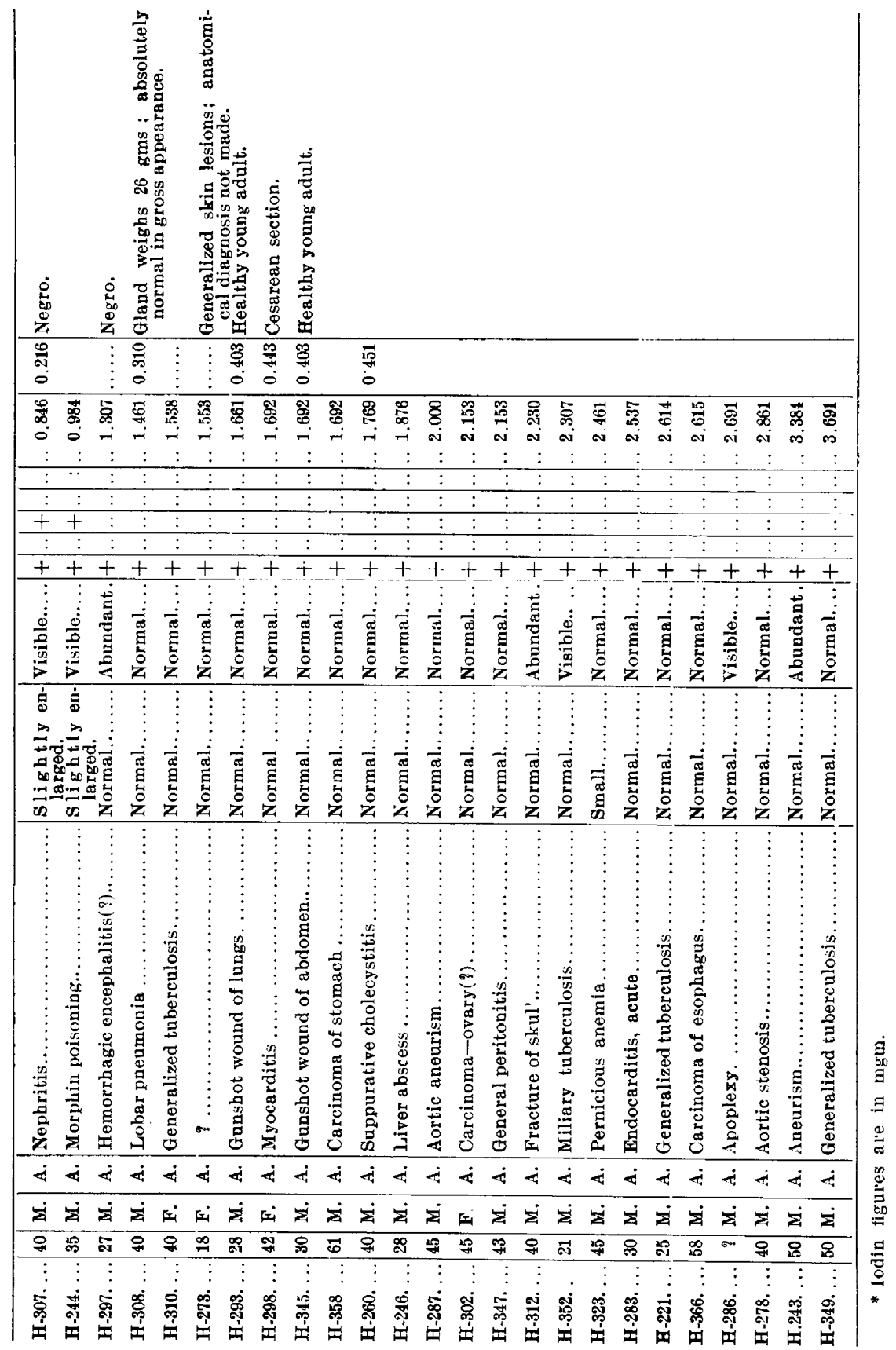


important in the anatomical study of goiter formation, so also are the earliest deviations from the lowest iodin content compatible with normal structure. As we have just seen, the iodin content of normal glands varies within extremely wide limits, so also does the iodin content of pure colloid glands. But, on the other hand, the lowest iodin content compatible with normal structure and the highest iodin content associated with the hyperplastic changes vary within extremely narrow limits, and, further, these limits are practically the same for four out of the five animals studied. (Why the ox thyroids should show an exceptionally high lower limit of iodin compatible with normal gland structure is not clear. In an earlier paper we have suggested it might be a biologicai [species] characteristic, inasmuch as these animals have relatively small thyroids.) It will be recalled that in the normal glands the highest amounts of iodin observed were also quite constant, being 4.614, 4.722, $4.153,4.768$, and $3.691 \mathrm{mgm}$. per gram of dried gland, for sheep, dog, pig, ox and man respectively. 'This observation, when taken in connection with the quite constant lower limit of iodin necessary for the maintenance of normal structure, adds weight to the view first suggested by the iodin feeding experiments-viz., that there is a definite limit to the combining capacity of the protein for iodin, and that any excess of iodin beyond this is excreted. Such a view would accord with the fact that iodin given to animals with glands in the stage of active hyperplasia has an action like desiccated thyroid, in that it increases the nitrogenous excretion and causes loss of body weight, while iodin not in the form of desiccated thyroid administered to dogs with histologically normal or colloid glands does not produce these effects on metabolism.

Passing to the other degree of hyperplasia it is seen that, instead of the great drop in the iodin content noted between "normal" and "normalearly" glands, the loss of iodin, while progressive, is more gradual and reaches its lowest point in the marked glandular hyperplasia group. This is true for all animals. Of the seven cases of marked glandular hyperplasia six were from cases of exophthalmic goiter and one from a case of pernicious anemia. This is important. In the first place, it shows that in this locality the goiters of the exophthalmic group constitute the most frequent types of pure marked glandular hyperplasia, although we have frequently seen nearly as marked types of hyperplasia without the clinical complex of exophthalmic goiter. It also indicates that these forms are less frequently treated with iodin-containing compounds than are the forms occurring in childhood, puberty, pregnancy, etc.

2. The colloid series of hyperplasias (see Fig. 9 and Tables 8, 13 and 16) is in general similar to that of the normal series. We have 


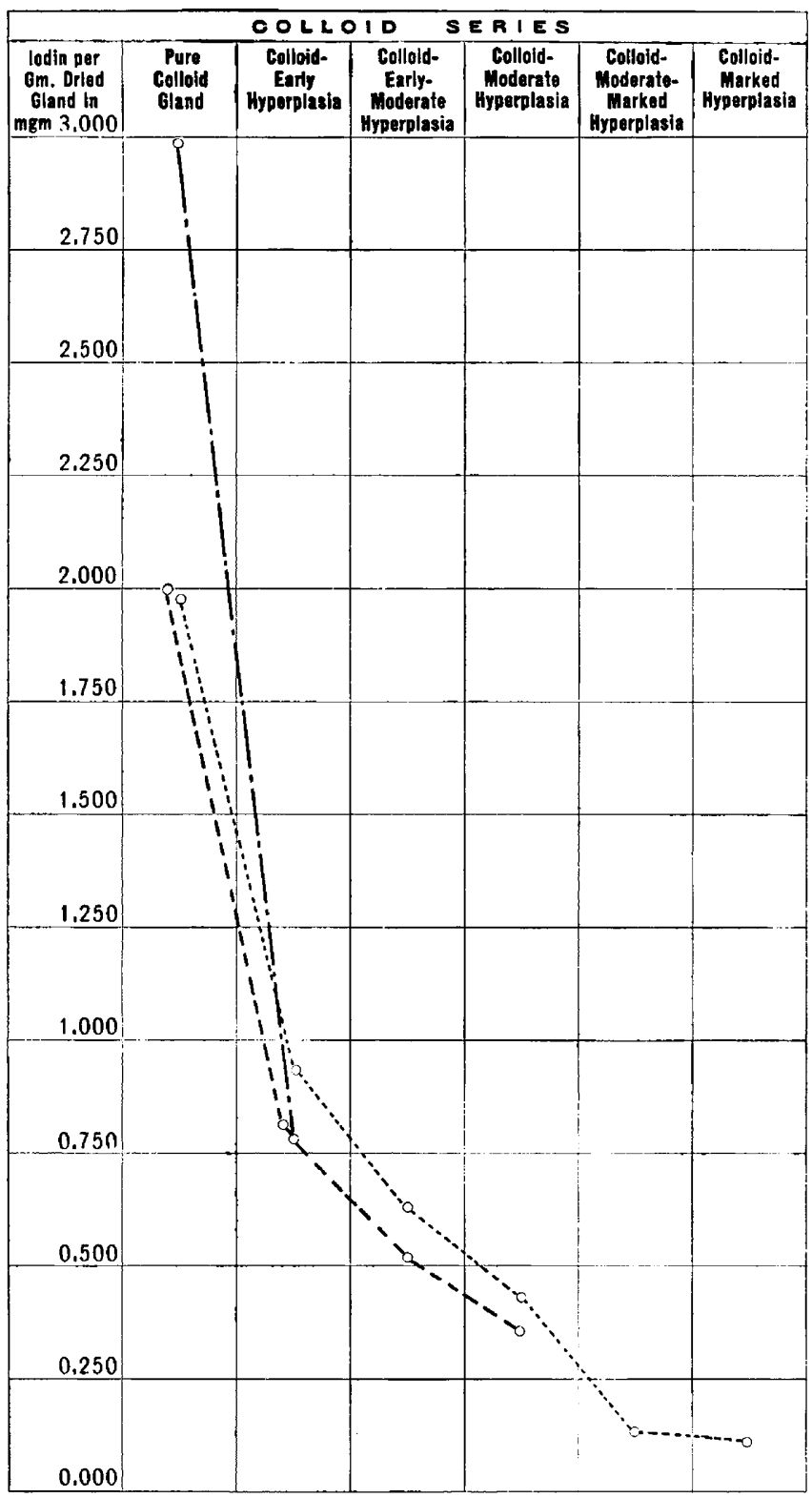

Fig. 9.-Curves compiled from the average iodin contents per gram of dried gland of the colloid series of hyperplasias in man, the dog and the pig, represented, respectively, by lines of the same character as in Figure 8. 
observed the complete series in the dog. Our human series is incomplete, for the reason that complicating factors such as hemorrhages and scar formations, the result of previous hyperplasia, were present, and, having excluded such cases from the normal series, we had also to exclude them from this (colloid) series. The reason for exclusion was, in both series, the possibility of these complications modifying the findings. The general histological picture and the iodin contents of the colloid series are similar to those of the normal series. In the dog the normal and colloid series are parallel. In the human colloid series, as in the normal series, the most striking feature is the great drop in the iodin content that occurs in pure colloid glands before hyperplastic changes begin. Its physiological significance is the same and means that colloid glands are the nearest to normal that glands which have once undergone hyperplasia can become; also, that colloid glands react to the same stimuli as do normal glands. That the colloid series should show more irregularities than the normal series is to be expected. First, the size of colloid glands is more variable, as compared with the quite constant size of the normal glands; therefore, the same total amount of iodin in glands of variable size would give quite variable iodin content per gram of dried gland. Most of the large glands, however, were complicated by hemorrhage or degenerative changes and were not used. Second, the duration of the goiter, the presence of cysts, hemorrhage or degenerations, interference with the normal lymphatic drainage by pressure, fibrosis, etc., the effects of medications ( $x$-ray, etc.), all modify the iodin-containing capacity of the tissue and its physiological value to the organism. In consequence of the presence of these many factors it is noteworthy that the parallelism between colloid and normal glands in the human series should be so close. In the lower animals, where many of these modifying factors are absent, a still closer parallelism exists.

\section{COLLOID GLANDS *}

There were twenty-five human glands in the colloid group. The extremes of iodin content were 3.914 and $0.784 \mathrm{mgm}$. per gram of dried gland. These extremes are somewhat greater than those of normal glands. So also colloid glands of dogs show greater extremes (3.608 and $0.846 \mathrm{mgm}$.) than the normal glands of dogs. This is to be expected, for the reason that colloid glands are of more variable size (usually larger) than are normal glands, and also for reasons indicative of a more complicated life-history, many of the factors of which are still unknown

\footnotetext{
* See tables 8 and 16 .
} 
TABLE 16.-COILOID SERIES-MAN

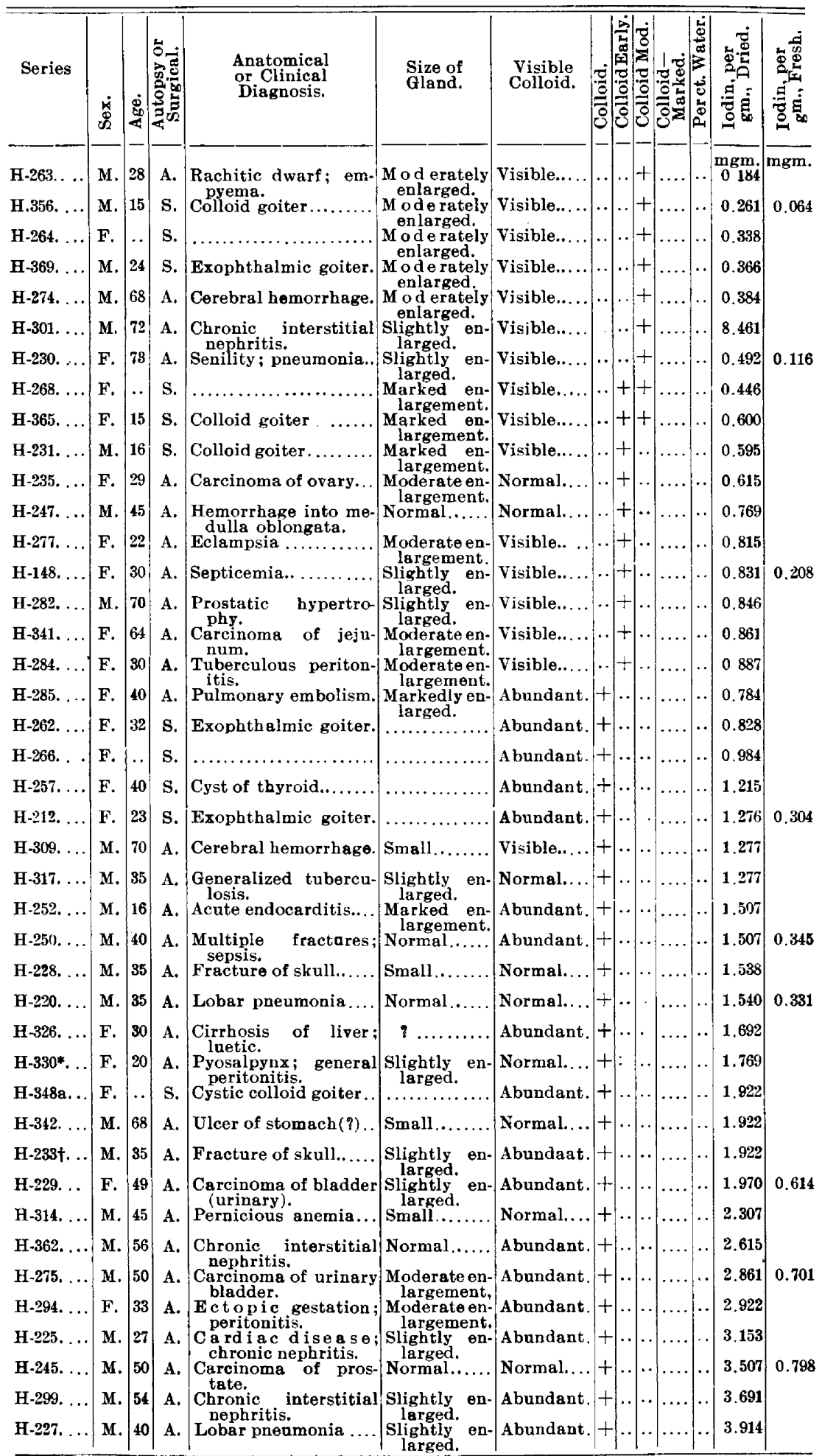

* Negress. † Healthy young adult. 
-e. g., the condition causing the hyperplasia, or the condition causing the involution (reversion). The mean and average iodin contents of colloid glands are but little below the mean and average of normal glands. This is probably accidental, for the reason that most of these cases are autopsy specimens, and many of them had received iodin medication. Reference to Table 16 shows that the iodin content of the colloid glands can be raised to the same degree as that of normal glands. It is also seen that the iodin contents of colloid glands are the nearest approach to those of normal glands that one meets, a fact which supplements their anatomical similarity to normal glands. Thus, just as in the normal series, so in the colloid series, the greatest drop in iodin content occurs between pure colloids and the first detectable hypertrophic or hyperplastic changes. With a single exception, clearly dependent on the size of the gland, the lowest iodin content associated with a pure colIoid gland is above the highest iodin content associated with active hyperplasia. In the case of colloid glands one can not say at what level of iodin per gram of gland hyperplastic changes would become manifest unless it is possible to work with glands more or less constant in size and free from complications. In our series as in our dog series it has been possible to work with colloid glands but slightly different from normal glands. With such a series it is easy to prove that colloid glands are similar to normal glands as regards their iodin contents.

\section{NORMAL-COLLOID GLANDS *}

This group of eight glands has been separated for the reason that histologically we could not decide whether they were normal or colloid. If they had undergone hyperplasia it was exceedingly slight. On the other hand, the size of the glands, their stroma and the outline of the vesicles did not fit the usual picture of normal glands. The iodin content closely resembles both normal and colloid glands as regards the extremes, mean and average. Ordinarily these glands would be considered normal, and they are normal as regards any physiological or clinical significance.

RELATION OF SEX, AGE, AND SIZE OF THE GLAND TO THE IODIN CONTENI; IODIN IN THYROID TUMORS

We have not observed any difference in the iodin contents of thyroids referable to sex, either in man or in the lower animals. Slight differences in the iodin content, if present, could not be detected by the pres-

\footnotetext{
* See Table 14.
} 
ent methods of examination, while slight differences in the weights of the glands are more easily detected.

As regards age, Baumann ${ }^{47}$ was the first to report differences. Since then all subsequent observers have confirmed his general conclusions, that iodin is lowest (in some cases absent) in infants' thyroids, gradually rises during the period of growth, continues more or less constant during the middle period of life ( 25 to 55 years), and finally falls slightly in old age. As regards the presence of iodin in infants' thyroids, different observers have reported different results. Thus Weiss ${ }^{48}$ reports 8 cases, the patients being from 24 days to $71 / 2$ years of age, all of which showed traces of iodin. Baumann ${ }^{47}$ in 17 Freiburg cases, patients from 1 day to $\%$ years of age, found iodin present in 12 . In 5 cases from Hamburg, from 5 days to 1 year of age, it was present in all. Von Rotsitzky ${ }^{49}$ found iodin present in 6 of 8 cases, while Miwa and Stöltzner ${ }^{50}$ found iodin in all of the 6 cases examined. Oswald ${ }^{51}$ also reports positive findings in all his cases. Jolin ${ }^{52}$ found iodin present in 20 of 27 cases examined. We have examined 10 subjects under one year of age and found iodin present in all. The highest was $0.482 \mathrm{mgm}$. per gram of dried gland, the lowest (an infant 1 month old) $0.027 \mathrm{mgm}$. per gram of dried gland. We have not examined any human thyroids at birth. In puppies whose mothers have been fed iodin we have detected it in glands at birth in all cases; while we have not detected any iodin in the thyroids of puppies whose mothers had not been fed iodin during pregnancy. Nagel and Roos ${ }^{53}$ have recorded similar observations. Hunt and Seidell ${ }^{54}$ from the results of their examinations and experiments favor the view that iodin is not uncommonly absent at birth and that the protection which such thyroids offer to mice against acetonitrile poisoning may be due to some other constituent of the protein. From the above references of recorded observations it is seen that iodin to the extent of mere traces has been found in most cases. However, findings negative to the tests at present in use, do not mean that iodin was altogether absent, and before it can be said that iodin is normally absent at birth more accurate methods of iodin determination must be devised.

47. Baumann: München. med. Wchnschr., 1896, xliii, 309.

48. Weiss: München. med. Wchnschr., 1897, xliv, 6.

49. Von Rotsitzky : Wien. klin. Wehnsehr., 1897, x, 823 .

50. Miwa and Stöltzner: Jahrb. f. Kinderh.. 1897, xlv, 871.

51. Oswald: Ztschr. f. physiol. Chem., 1897, xxiii, 265.

52. Jolin: Festschr. f. O. Hammersten, 1906.

53. Nagel and Roos: Arch. f. Anat. u. Physiol. Supplementary Volume, 1902. p. 267.

54. Hunt and Seidell: Bull. 47, P. H. and M.-H. S., 1909, p. 49. 
There is no doubt that iodin may be aissent (undetectable) at birth, for the same reasons that it is in older animals (hyperplasia, cretinism).

In old age there is a slight decrease of iodin, associated with and perhaps parallel with senile atrophy. Thus, in our series, there were seven (not included in the tables) normal senile glands. The highest iodin content was $1.584 \mathrm{mgm}$., the lowest $1 \mathrm{mgm}$, and the average 1.299 mgm. per gram of dried gland, as compared with 3.691, 1.30\%, and 2.171 mgm. respectively for uncomplicated histologically normal glands. In conclusion it may be stated that, while age bears a quite constant relation to the iodin content, it is one of the least important factors influencing the iodin content.

The relation of the total iodin to the size of the thyroid, when taken by itself, has little value. This relationship has been the subject of many controversies between those who sought to show that iodin was related to goiter formation and those who sought to show that iodin was merely accidental. All workers have agreed that in general goiters tend to contain less iodin than normal glands. To this there are many exceptions, however. These exceptions could probably be explained, as we have previously pointed out, by comparing the histological structures with the iodin contents. We have made such comparisons in the sheep, dog and man, and have found that, as a rule, colloid goiters have more iodin (total) than have normal glands, while active hyperplasias for all the animals examined have much smaller total iodin contents than normal glands. ${ }^{5 s}$ Therefore, any discussion of the relation of iodin to the size of the glands is useless unless it is based on the more important factor of histologic structure. In general it may be stated that all actively hyperplastic glands have a smaller total jodin content than normal glands; and that the total iodin varies inversely with the degree of glandular hyperplasia. On the other hand, all pure colloid glands usually bave more iodin than the minimal normal content (though, as a rule, per gram of dried gland, colloid glands have less iodin than normal glands). The total amount of iodin that a gland may contain obviously depends on its size, the accidental circumstances of food, medication, locality, etc. Oswald, ${ }^{56}$ and all subsequent observers, have shown that the colloid of colloid glands (goiters) may contain as high a percentage of iodin as the colloid of normal glands, and that such colloid has the same physiological activity as colloid from normal glands.

55. Marine and Lenhart: Further observations on the relation of iodin to the structure of the thyroid gland in the sheep, dog, hog and ox. The Archrves In's MED., 1909, iii, 66 .

56. Oswald: Virchow's Arch. f. path. Anat., clxix, 444. 
The presence of iodin in thyroid tumors is also of interest and may be referred to at this time. It is the rule to find iodin in fetal adenoma. We have examined nine such tumors and have found iodin in eight. The highest iodin content was $0.593 \mathrm{mgm}$. per gram of dried tumor, while the average content of the eight cases was $0.174 \mathrm{mgm}$. The specimen in which no iodin was demonstrable was removed at operation, together with some of the surrounding original thyroid tissue, which histologically was pure colloid gland (goiter) and contained $1.922 \mathrm{mgm}$. of iodin per gram of dried gland. The tumor had the usual characteristics of fetal adenoma. It was a round, encapsulated, soft, grayish, cellular mass of tissue 4 by 4 c.m., and histologically was composed of uniform, small, undistended alveoli lined with cubical epithelium. In these benign tumors the iodin content varies with the structure just as in the simple hyperplasias, being lowest in the very cellular actively growing tumors and highest in those that have undergone involution (reversion) to the colloid state. We have examined metastases from two cases of thyroid carcinoma in dogs, but found no iodin.

\section{SUMMARY AND DISCUSSION}

When all the glands are arranged according to their histological structures with normal or colloid glands at one end and the marked hyperplasias at the other, as in the full tables (Nos. 15 and 16), it is seen that the normal and colloid glands have the highest and the marked hyperplasias the lowest iodin contents. This is true for all the animals examined. It also shows that the iodin varies with the amount of stainable colloid; inversely with the size of the glands (in hyperplasias) and inversely with the degree of active hyperplasia. These relations were earlier shown to be true of dog, sheep, ox and pig thyroids. Such constant relations of iodin to the gland structure can not be accidental when taken in connection with other established facts. Thus Roos ${ }^{43}$ has shown that the physiological action of desiccated thyroid (as ascertained by the nitrogen excretion) varies directly with the amount of iodin in organic combination. Oswald ${ }^{51}$ repeated this work, using thyreoglobulin from normal and from goitrous glands with the same results. He also showed that the action of thyreoglobulin of goitrous glands was not different (qualitatively) from that of normal thyreoglobulin. Hunt and Seidell ${ }^{54}$ have obtained similar results with the acetonitrile indicator. Although at first disputed, it is now abundantly confirmed that the beneficial effect, clinically, of desiccated thyroid on goiter is parallel with its iodin content. We have shown ${ }^{55}$ that the administration of iodin to animals with active hyperplasia has the same pharmacological 
effect that desiccated thyroid has on normal animals. Further, it has been shown that feeding any iodin-containing compound very quickly (in three or four weeks) causes hyperplastic glands to revert, and that this change is associated with the rapid accumulation of iodin in the gland. It is of little or no consequence whether the hyperplasia occurs in man or animals, or whether it is associated clinically with myxedema (cretinism) or with exophthalmic goiter. So also it has been pointed cut that iodin prevents the occurrence of fetal thyroid hyperplasia in puppies whose mothers have had most of their thyroids removed. Also it has been shown that iodin will prevent the compensatory hyperplasia following partial removal of the thyroid. In the presence of sufficient doses of iodin all true hyperplasia is prevented. Such evidence, it seems to us, is the highest or biological proof that iodin is an active, perhaps the most active, constituent of the thyroid secretion. Recent observations by Fassin $^{57}$ and Marbés8 indicate that iodin markedly raises the alexic (opsonic) activity of the blood serum. This is perhaps of great interest in that it may tend to explain why iodin benefits certain chronic inflammatory processes, and also why cretinoid animals manifest very low resistance to infectious agents. All of these facts show that during the active growth of the goiter there is a deficiency of iodin in the thyroid. This general observation recalls to mind the extensive chemical analyses that were made by Prevost and Maffoni, ${ }^{59}$ by Niepce, ${ }^{60}$ by Marchand ${ }^{61}$ (quoted by St. Lager), and, more particularly, by Chatin, ${ }^{61}$ and their conclusion that goiter was due to lack of iodin. They attributed the deficiency to a lack of iodin in the water and air, pointing out that along the seacoast, and in localities where iodin was present in relatively large quantities, goiter did not frequently occur. Their methods of chemical analysis were faulty, and their conclusion was easily overthrown by the extensive examinations of water, air and soil that followed. It seems now firmly established that there is an actual deficiency of iodin in the thyroid during the stage of active hyperplasia. On the other hand, the vast collections of statistical evidence on the iodin content of waters and foods, as well as the occurrence of goiter in some and not in other members of groups of men living under the same conditions of food and water, as in schools, barracks, garrisons, etc., would leave little doubt that the deficiency of iodin was not commonly due to a lack

57. Fassin: Compt. rend. Soc. de biol., Paris, 1907, lxii, 390; 1909, lxvi, 457.

58. Marbé: Compt. rend. Soc de biol., Paris, 1909, lxvi, 432.

59. Maffoni: Atti d. Accad. med.-chir. de Torina, 1846, ii, 453.

60. Niepce: Traite du goitre et du crétinisme, 1852, ii.

61. Quoted by St. Lager: Etudes sur les causes du crétinisme, Paris, 1867. 
of iodin intake. Therefore, it would seem that some other agents or factors were operating in these cases. As is well known, many, indeed almost all the ordinary mineral substances, infectious agents, etc., have from time to time been accused. The infectious origin has been supported by Virchow, Bircher, Kocher, Hirsch and others, and reached its greatest popularity during the early period of bacteriological investigation (1850-85). Since Schiff, Wagner and Halsted ${ }^{26}$ first established the fact that compensatory hyperplasia normally followed removal of the gland, and that this hyperplasia was in no way different from the changes in developing goiters, the infectious theory has been declining, while the nutritional or metabolic view has been gaining. To be sure, changing the water-supply and boiling the water have been associated with a decrease of goiter. But this could scarcely be any greater argument for an infectious origin of goiter than for a metabolic (chemical) one. But, whatever the ultimate causal factor is shown to be, it is certain that there is a deficiency of iodin in the gland, and that this deficiency of iodin in the gland is not usually due to a lack of iodin intake, but is dependent on a lack of absorption or assimilation of iodin. And it is our belief that one or more chemical substances will be found which are antagonistic to or inhibit the normal absorption or assimilation of iodin.

RELATION OF IODIN CONTENT AND HISTOLOGICAL STRUCTURE TO DISEASI: PROCESSES IN GENERAL

Any discussion of the relation of the thyroid to disease processes must take account of both the histological structure and the iodin content of the thyroid, since these two factors have the following constant relation: The iodin content varies inversely with the degree of active hyperplasia. Is this relation merely accidental or is it one of cause and effect? Sufficient data are now available to prove that this relation is not accidental. These data may be summarized as follows:

1. Partial removal of the thyroid is normally followed by compensatory hyperplasia of the remaining portion. The extent of the resulting hyperplasia is known to depend on the age of the animal, the amount of gland removed and the quality of the food. Horsley, ${ }^{62}$ Halsted, ${ }^{28} \mathrm{Ma}$ rine, ${ }^{4}$ Marine and Williams. ${ }^{4}$

2. Withholding iodin increases the extent of the hyperplasia following partial removal (Marine ${ }^{4}$ ), and also causes hyperplasia without partial removal (Baumann ${ }^{42},{ }^{47}$ ).

62. Horsley: Proc. Roy. Soc., London, 1886, xl, 6. 
3. The administration of iodin causes active hyperplasias of all animals to revert to the colloid state; prevents the occurrence of active hyperplasia following partial removal of glands which otherwise would undergo hyperplasia.

4. The administration of iodin prevents hyperplasia of the thyroids of puppies from bitches in which three-fourths of the gland has been removed.

5. Normal thyroids of all the animals examined have the highest and marked hyperplasias the lowest iodin contents.

6. The administration of iodin-containing compounds to the animal in any form and by any method is rapidly followed by its storage in the thyroid in quantities that bear no relation to the iodin content of the other tissues.

7. The rapidity of accumulation and the amount of iodin thus taken up by the thyroid depend on its size and the degree of active hyperplasia.

8. The physiological activity, as determined by the nitrogen excretion $\left(\right.$ Roos, ${ }^{43}$ ), by the loss of body weight (Marine and Lenhart ${ }^{2},{ }^{55}$ ), and by the acetonitrile reaction (Hunt, ${ }^{44}$ Hunt and Seidell ${ }^{54}$ ), depends principally on the amount of iodin in organic combination.

9. It has been shown (Marine and Williams, ${ }^{4}$ Marine and Lenhart $^{2},{ }^{55}$ ) that in dog, sheep, pig, ox and human thyroids there is a quite constant minimum percentage of iodin necessary for the maintenance of normal gland structure.

While practically nothing is known of the causes leading to the iodin deficiency in the animal, the above facts, beyond doubt, show that the increased growth and divisional activity of the thyroid cells are intimately associated with a decrease of iodin, and that the increased iodin content is similarly associated with a decreased growth and divisional activity of the thyroid cells. On this basis one would expect to find thyroid changes resulting from any cause which diminished the intake or assimilation of, or increased the body demands for iodin, and that, therefore, all thyroid changes would be compensatory in nature and secondary to more fundamental causes, perhaps nutritional in nature. Also we would expect to find active hyperplasia (goiter) always preceded and accompanied by other systemic disturbances, especially those of a nutritional nature. There are other views regarding the nature of thyroid hyperplasia. Thus it is looked on by many as an infectious process in which some specific organism plays a primary rôle. The arguments for this view are of the same nature as those advanced in support of the microbic etiology of cancer. They need not be discussed here. 
Another view, advanced by Gauthier ${ }^{63}$ and Moebius, ${ }^{64}$ is that certain types, at least, of thyroid hyperplasia are primary processes. This view is particularly applied to exophthalmic goiter, and implies that the thyroid changes are idiopathic and spontaneous, and that the thyroid abnormality by means of a hypersecretion or perverted secretion causes the disease. Without going further into the almost countless theories regarding the nature of the thyroid reaction, most of which have only an historical interest, it may be said that the three views above mentioned are the only active ones at present and may be summarized as iollows: 1. Active hyperplasia is a compensatory and secondary reaction to a disturbance of nutrition. 2. It is the result of a specific infectious agent. 3 . It is a primary thyroid disturbance.

A great variety of diseases are associated with or accompanied by noticeable thyroid changes. Thus rickets, lymphatism, chlorosis, cretinoid states and osteomalacia (?) are practically always associated with anatomical changes in the thyroid. Many of the prolonged infectious diseases, as lues, typhoid fever, influenza, acute articular rheumatism and tuberculosis, are frequently associated with or followed by thyroid hyperplasia. In individuals with adenoids and enlarged tonsils (lymphatism) (?), in abnormally fat children and in adiposis dolorosa, ${ }^{65}$ the association is not infrequent. In conditions in which mental and nervous fatigue have lasted for prolonged periods of time, as in neurasthenia, and in prolonged mental states produced by worry, shock, anxiety, overwork, etc., thyroid changes are frequently observed. Also there is a particular association of thyroid changes with the systemic changes taking place at puberty; with the menstrual function; with pregnancy and lactation, and with the menopause. Lastly, thyroid changes are perhaps most frequently seen in the poorly fed and poorly nourished young (puppies, lambs, calves and children).

While all the groups of disease processes above enumerated have long been associated with thyroid changes, by some writers as cause and effect, by others as accidental, it is clear that they represent only a portion of the factors or agents capable of instituting conditions of nutrition favorable for the development of thyroid hyperplasia. Thus, while thyroid hyperplasia (goiter) may occur anywhere, it is particularly associated with certain localities. Thus far nothing specific in the geology, climate, food or otherwise has been found to account for this increased

63. Gauthier: Rev. de méd., $1890, x, 409$.

64. Moebius: Centralbl. f. Nervenh., 1887, x, 225.

65. Price: Am. Jour. Med. Sc., 1909, exxxvii, 705. Guilliam and Alquier: Arch. de mêd. expêr. et d'anat. path., 1906, xviii, 680 . 
frequency. We believe, however, that some agency or factor will be lound in these districts that operates to produce hyperplasia by interference with the normal chemical processes of the body.

As was first pointed out by Hale White, ${ }^{9}$ if one examines any large series of human thyroids he will find a considerable number showing hyperplastic changes in cases in which the subjects during life showed no symptoms known to be associated with thyroid disease. His observations have been abundantly confirmed, not only for man, but for the lower animals as well. Indeed, it is most striking in carnivora. Thus 90 per cent. of the dogs in this district have active thyroid hyperplasia, and yet, so far as we are at present able to detect clinically, most of these dogs are normal. This does not mean, however, that such animals have no symptoms directly associated or parallel with the thyroid changes. For we know that after these changes have reached a certain degree all animals show clinical manifestations. It rather indicates that the thyroid is extremely sensitive to stimuli and that the symptoms produced in most cases are below the present level of clinical detectability. In man the greater proportion of thyroids showing histological changes toward goiter formation are not associated with detectable clinical manifestations. Most of these milder degrees of thyroid changes spontaneously right themselves when the underlying or accompanying disease disappears, as, for example, the hyperplasia associated with influenza, or typhoid, or pregnancy, etc., rarely comes to clinical notice. Thus it is that all autopsy series show such a great proportion of thyroid changes without detectable clinical manifestations.

Thus far we have been discussing thyroid changes only, but it must not be overlooked that these changes are as a rule associated with other tissue reactions. The lymphoid tissues and bone marrow are very frequently hypertrophied as well. This association may be present in all the clinical forms of goiter, including cretinism. It is most frequently noticed, however, in exophthalmic goiter and in cretinism. This very common association with exophthalmic goiter was first recorded by Markliam $^{68}$ and is now recognized as a constant accompanying condition in all the severe cases. There are differences of opinion as to the significance of these changes, particularly in exophthalmic goiter. Thus, Boit ${ }^{6-}$ and Capelle ${ }^{68}$ regard the condition as lymphatism associated with exophthalmic goiter. Hansemann, ${ }^{16}$ Hirschlaff $^{13}$ and others think that the

66. Markham: Tr. Path. Soc., London, 1858, ix, 163.

67. Boit: Frankf. Ztschr. f. Path., 1907, i, 187.

68. Capelle: Beitr. z. klin. Chir., 1908, lviii, 353. 
thymic enlargement is due to thyroid toxins. Hart ${ }^{69}$ thinks that the thymus toxins start the thyroid changes. Last, there is the view supported by Marie, ${ }^{70}$ Hektoen, ${ }^{71}$ Marine ${ }^{4}$ and T. Kocher ${ }^{72}$ and others, that these changes are a part of the disease. Whether the association is merely coincident or is dependent on some other as yet unknown nutritional disturbance is not determined. The present knowledge would indicate a very close relationship between goiter and lymphoid hyperplasia and, since lymphoid hyperplasia is also common in rickets, chlorosis and lymphatism, it would indicate that if these diseases, in common with goiter, have specific causal agents, these agents are all frequently active at the same time and in the same individual.

Finally the question arises: Are the thyroid changes associated with the diseases above enumerated identical as regards their anatomy, their chemistry and their biological reactions? So far as we are able to detect these changes, they are identical. In all there is the lowering of the iodin inversely with the degree of hyperplasia. The histological picture is identical in all, and they react alike to iodin-containing compounds. The changes in exophthalmic goiter are considered by many to be separate and distinct, and will be discussed separately.

To sum up: It is seen that active hyperplasia accompanies and follows a great variety of clinical diseases: that it is far more commonly and easily detected anatomically than clinically; that with whatever disease associated, the anatomical changes are the same; the iodin content varies in the same way in all, and they all react alike to iodin-containing compounds; that changes in the lymphoid tissues are frequently observed along with goiter, and also with other diseases with which goiter is frequently associated. On this evidence we conclude that the thyroid changes are not specific or primary, but are only the result of stimuli, constant perhaps, arising in the course of many nutritional disturbances (diseases).

RELATION OF THE IODIN CONTENT AND THE HISTOLOGICAL STRUCTURE TO EXOPHTHALMIC GOITER ${ }^{73}$

It is concerning the recognition and the separation of the essential from the accidental findings in exophthalmic goiter that the difficulties and controversies have arisen. This is true of both the clinical and the

69. Hart: München. med. Wchnschr., 1908, Iv, 668.

70. Marie: Gaz. d. hôp., 1893, 202.

71. Hektoen: Internat. Med. Mag. Phila., 1896, iv, 584.

72. Arch. f. klin. Chir., 1908, lxxxvii, 131.

73. Dock (Jour. Am. Med. Assn., 1908, li, 1119) has lately reviewed the question of the appropriate name for this disease and we agree with him in preferring the term "exophthalmic goiter," though an objectionable one, to such designations as "Flajani's," "Parry's," "Graves"” or "Basedow's disease." 
laboratory observations. The amazing quantity of literature that has accumulated about this disease in the past twenty-five years clearly indicates that neither clinical studies alone nor anatomical studies alone, nor the combination of these alone, will accurately define what should be included under the term exophthalmic goiter.

This disease is associated with and in all probability depends primarily on nutritional disturbances, the nature of which is not determined, and it is not even known whether they are fundamentally the same in all cases. The anatomical changes, the iodin relations and the general phenomena of the disease will be discussed in the order named. The riews as to the relation of the anatomical changes may be grouped under three headings: (1) the view that the thyroid changes are constant and specific; (2) that the anatomical changes have no particular relationship to the disease; (3) that the anatomical changes (hyperplasia), while constantly present at some stage in all cases, are also prescnt at some stage in all true goiters.

The view that the thyroid changes (hyperplasia) in exophthalmic goiter are constant and specific had been supported by Greenfield, ${ }^{13}$ Farner, ${ }^{25}$ Bramwell, ${ }^{12}$ Hämig, ${ }^{74}$ MacCallum, ${ }^{18}$ Lewis, ${ }^{20}$ Ewing, ${ }^{19}$ Wilson $^{21}$ and others.

The view that there is no particular relationship between the anatomical changes and the disease has been supported by Virchow, ${ }^{75}$, Renaut and Brissaud, ${ }^{76}$ Reinbach, ${ }^{77} \mathrm{~A}$. Kocher ${ }^{78}$ and many others. These are the extremes. Neither view fully accords with the facts. On the one hand, the hyperplasia is not common to this disease alone, while, on the other hand, this hyperplasia occurs at some time in all true cases of exophthalmic goiter. The explanation of the fact that one often sees colloid goiter associated with the symptom-complex of exophthalmic goiter is that the thyroid may undergo very rapid histological changes without correspondingly rapid changes in the symptoms.

Thus we have seen cases with marked hyperplasia under the influence of small doses of iodin revert to colloid goiter in from three to four weeks, while the clinical manifestations remained practically the same. As a rule, however, the symptoms become less marked as the involution (reversion) to colloid goiter occurs. Thus the histological condition of the specimen at the time of removal may be quite different from what

74. Hämig: Arch. f. klin. Chir., 1897, lv, l.

75. Virchow: Die krankhaften Geschwülste, iii, 75.

76. Renaut and Brissaud: Semaine méd., 1895, Yo. 39.

77. Reinbach: Mitt. a. d. Grenzgeb. d. Med. u. Chir., 1901, viii, 247.

78. Kocher, A.: Mitt. a. d. Grenzgeb. d. Med. u. Chir., 1902, ix, 1. 
it would have been even two weeks before. Similar histological changes to those in exophthalmic goiter are also seen in all developing functional hyperplasias of man and animals. There are differences of degree and differences depending on the age of the animal, the number of times the gland has reverted and undergone hyperplasia, the presence of complications, etc., as outlined above. The reaction with iodin is the same in all forms of functional hyperplasia. The marked hyperplasias of exophthalmic goiter react exactly in the same way as do the hyperplasias in animals or the hyperplasias of childhood, puberty and pregnancy in man.

In the light of these facts the third view-viz., that active hyperplasia is of constant occurrence at some phase in all true cases of exophthalmic goiter but that similar changes occur in all developing goitersis the one most likely to accord with all the facts.

Of 26 cases clinically diagnosed as exophthalmic goiter in which the patients were operated on by Dr. G. W. Crile at Lakeside Hospital 15 had active hyperplasia, varying from colloid-early to marked glandular hyperplasia. Eight had pure colloid goiters. Two had pure colloid goiters containing actively growing fetal adenomata and one had a normal thyroid as regards size, histology and iodin content. With this series one would be inclined to agree with Virchow ${ }^{74}$ when he wrote that the phenomena of exophthalmic goiter depended on neither a distinct variety of goiter, nor a distinct size, nor yet a distinct stage of thyroid change, did we not further inquire into the cases. It was found that the patients with pure colloid goiter had been treated with iodincontaining substances shortly before operation. These cases clinically were quite typical cases of exophthalmic goiter. This finding bears out the observations reported from most of the large clinics that one frequently sees cases of exophthalmic goiter with colloid glands. This, however, means that the thyroid reacts too quickly (three to four weeks) for the clinical manifestations to follow and not that in the progressire stage of the disease there was no active hyperplasia, for we now know that all colloid goiters have been preceded by active hyperplasia. We also know that the histological appearance of the thyroid may change from week to week and there can be little doubt that the varied histological findings reported by all observers is due merely to the stage of the process (regressive or progressive) at the time of the operation. The case in which the thyroid was normal is not unique. There are several reports of such cases. These cases must either be considered errors in diagnosis or that the manifestations were too recent for cell reactions to occur. We are inclined to consider such cases not true exophthalmic 
goiter, but rather as severe cases of some clinically closely allied disease like neurasthenia or psychasthenia.

Thus, after carefully reviewing the data, we conclude that thyroid hyperplasia is of constant occurrence at some stage of the disease, but that it also occurs in all developing goiters in all animals.

IELATION OF THE IODIN CONTENT OF THE THYROID TO EXOPHTHALMIC GOITER

The iodin varies inversely with the degree of hyperplasia. We have just seen that the histological structure of the goiters as we obtain them is quite variable; so also is their iodin content. But, just as there is a constant histological change (active hyperplasia) at some phase in all true cases of exophthalmic goiter, so there is a uniform lessening of the iodin content corresponding with the increasing degree of hyperplasia. Oswald ${ }^{79}$ in general found the percentage of iodin lowered in exophthalmic goiter, but he also observed cases in which it was increased. Caro $^{80}$ in a single severe case found the iodin very high. Reinbach ${ }^{81}$ could make out no relation between the amount of colloid and the amount of iodin. Kocher ${ }^{82}$ found exophthalmic goiter glands always lower in iodin than normal glands, even to one-thirtieth of the normal.

Two conditions must be fulfilled before one can conclude that iodin bears no relation to exophthalmic goiter: (1) a large series of cases, (2) careful histological comparisons. It seems that this may account for many of the reports in which no relation could be made out, just as it explains why constant anatomical changes were not established earlier. The histology and iodin content for human goiter are modified by so many factors that it is necessary to examine a large series in order to include and allow for variations dependent on the food, medication, age, stage of the disease, etc.

In our 26 cases there was no case in which the iodin did not vary inversely with the histological structure. It was highest in the colloid glands, lowest in the marked hyperplasias, and the highest iodin content associated with hyperplasia was always below the lowest associated with pure colloid gland. We can conclude, therefore, that the iodin content in exophthalmic goiter always varies inversely with the degree of hyperplasia just as in all other forms of active hyperplasia. There are the same difficulties in the interpretation of the anatomical changes. These

79. Oswald: Virchow's Arch. f. path. Anat., 1902, clxix, 444.

80. Caro: Berl. klin. Wchnschr., 1907, xliv, 519.

81. Reinbach: Centralbl. f. Chir., 1898, xxv, 545.

82. Kocher: Arch. f. klin. Chir., 1901, lxiv, 454. 
can only be avoided by working with large series and by carefully comparing the iodin content with the histology.

The severity of the cases in general varies with the degree of thyroid and lymphoid hyperplasia. Autopsy and surgical reports from all sources have shown this. In our series there were six patients with marked glandular hyperplasia, of whom four died. Of the four that died three had slight manifestations suggestive of supervening myxedema (dry skin, pigmentation, loss of pubic, axillary and scalp hair, etc.). The ten patients with colloid goiter recovered.

As to the cause of death after operation in these severe cases there are three views: (1) that it is due to the poisoning of the tissues with an excess of thyroid secretion; (2) that it is due to the lymphoid hyperplasia (status lymphaticus); (3) that it is due to true exhaustion of all the tissues, particularly the central nervous system.

The first view embodies the well-known theory of Moebius and Gauthier ${ }^{63}$ on which the surgical, the cytotoxic and serum treatments rest. Are these hyperplastic glands secreting an increased quantity of physiologically active secretion? If such were the case, the same changes should be produced in the thyroids of animals by feeding with hyperplastic glands as by feeding with normal or colloid glands. This, as is well known, is not true. The physiological activity of such thyroids, as determined by the nitrogen excretion and the histological changes produced in dogs' thyroids, depends on the amount of iodin they contain and the iodin varies inversely with the degree of thyroid hyperplasia. Also, the fact that desiccated sheeps' thyroid in large doses ( 2 to 5 grams daily) usually increases the clinical symptoms in proportion to the severity of the case can not be interpreted as proof of physiological hypersecretion, for the reason that the effect of such desiccated thyroid on these patients depends on the quantity of iodin it contains. That this is true can be easily shown by the fact that iodin administered to these cases has (so far as we are able to estimate) the same action as desiccated thyroid. In individuals with normal glands just the opposite of this is true. Iodin in similar doses has no noticeable effect, while desiccated thyroid produces the same manifestations of physiological activity as are shown in cases of exophthalmic goiter, and, also, just as in the exophthalmic goiter cases, the physiological activity depends on the amount of iodin in organic combination. The results of operative treatment according to the hypersecretion theory should be most favorable in those cases with the most active hyperplasia. As a matter of fact, the opposite is true-viz., that the operative mortality is greatest in those cases with the most marked hyperplasia and the lowest iodin contents. 
The clinical severity as determined by the symptoms is uncertain, for the reason that the gland may revert to the colloid state with the apparent preservation of the original symptoms. In such cases, as in the cases with slight hyperplasia, the mortality from operation is very low. And, therefore, the mortality, as based on the number of cases clinically diagnosed as exophthalmic goiter, is of little importance. Another view that squeezing or manipulation of the gland produces the marked rise in pulse rate and temperature (so-called hyperthyroidism) by overloading the circulation with the "toxic" secretion has been proved untrue, for the reason that operations elsewhere on the body or injuries, or even mental shock, in this class of cases are with proportionate frequency followed by these symptoms.

The second view that the lymphoid hyperplasia (status lymphaticus) is the determining cause of death in these cases has lately been revived and reviewed by Capelle. ${ }^{83}$ The presence of lymphoid hyperplasia in these severe cases of exophthalmic goiter was perhaps first described by Markham ${ }^{66}$ and later by Marie, ${ }^{70}$ Hektoen, ${ }^{71}$ Hansemann ${ }^{16}$ and many others. Capelle has found in the collected reports that 44 per cent. of the exophthalmic goiter patients dying of some intercurrent disease; 82 per cent. of those dying directly of the disease and 95 per cent. of those dying after operation had persistent thymus. From these data he concludes that this lymphoid hyperplasia is a separate and complicating condition in exophthalmic goiter. Others look on these changes as part of the essential anatomical lesions in all severe cases. The fact that these same changes are also present in cretin lambs, dogs and children, and also in many cases of adult myxedema, compels us to conclude that it is merely a part of the systemic reaction to the cause or causes producing goiter. We fully agree with Capelle that in all severe cases of exophthalmic goiter there is lymphoid hyperplasia, and also that the mortality is greatest in those cases, but we can not accept his conclusion that the mortality depends on the presence of lymphoid hyperplasia alone. We consider both the thyroid and lymphoid changes as common and the truest indices of the severity of the disease.

The third view is that death is due to exhaustion. This view, it seems to us, more nearly accords with the observed phenomena. All observations go to show that the gland is hyperactive, but that this activity is compensatory in nature. So also all the facts indicate that the quantity of the secretion is increased, but that its physiological activity is decreased. The frequency with which myxedema follows exoph-

83. Capelle: Beitr. z. klin. Chir., 1908, Iviii, 353; München. med. Wchnschr., I908, lv, 1826 . 
thalmic goiter can not be explained as accidental and, as has been suggested by several authors, is perhaps the greatest objection to the hypersecretion theory. In endemic cretinism, in both man and animals, one notes the same kind of anatomical changes as are observed in exophthalmic goiter, and, as already stated, these changes are common to all developing functional hyperplasias of the thyroid. This is, however, only the anatomical verification of the old clinical phrase that endemic goiter is the first stage of the process leading to cretinism and it seems to us, as $\mathrm{Ord}^{3},{ }^{24}$ has pointed out, that in myxedema following exophthalmic goiter, we have a very close analogy with cretinism. In this connection it is of great interest to note that Horsley ${ }^{62}$ in his experimental myxedema in monkeys has described a nervous stage followed by the duli listless stage so characteristic of fully developed myxedema, and also that McGarrison, ${ }^{36}$ in his excellent clinical report on cretinism in the Himalayas, has very carefully described this nervous stage. Whether these anatomical and clinical similarities between the life-history of exophthalmic goiter and of cretinism are closely related or are merely accidental is a problem that is worth very careful study. The nervous symptoms are, however, not common to this disease alone, but may be present in varying degrees in a variety of nervous and mental diseases in individuals with histologically normal thyroids, as in neurasthenia and psychasthenia. The same may be said of the symptoms of extreme tachycardia and high temperature which so frequently follow operations, injuries or mental shocks in these cases. The same phenomena are observed in heat exhaustion. The onset of the disease, while it may be quite sudden, is almost always progressive and preceded by some chronic debilitating disease as typhoid fever, influenza, or by severe mental strain as overwork, anxiety, etc. The whole clinical picture, it seems to us, is one of exhaustion, the seat of which is particularly the central nervous system. Certainly the nervous manifestations predominate and perhaps cloud (at least, by our present standards of interpretation) the true picture of exhaustion. It is difficult to understand why partial removal is so quickly followed by a further hyperplasia of the remaining portion which differs anatomically from the first portion removed in no essential way, and why in spontaneous recovery the gland always returns to the colloid state, unless we assume that the process of hyperplasia of the thyroid is a compensatory one..

In the light of our present knowledge of the anatomy, the chemistry and the biology of thyroid hyperplasia we can not conclude that the thyroid changes in exophthalmic goiter are either primary or specific or that such thyroids are producing an increased amount of a physio- 
logically active secretion. On the other hand, we believe that the thyroid changes in exophthalmic goiter are always compensatory or secondary to some more fundamental cause or causes and that there is a hypersecretion quantitatively but a hyposecretion qualitatively (physiologically), and, lastly, that the usual final stage of all cases unless terminated by death or relative recovery is myxedema.

RELATION OF THYROID CHANGES AND IODIN CONTENT TO CRETINISM AND MYXEDEMA

It is now generally accepted that the major disturbance in sporadic and endemic cretinism, in operative myxedema (cachexia strumipriva), and in natural myxedema (Gull's disease) is a lack of thyroid function. This opinion is largely the result of the clinical and anatomical observations from many sources, among which may be mentioned the work of Gull, ${ }^{23}$ Kocher, ${ }^{84}$ Ord, ${ }^{85}$ Hun and Prudden, ${ }^{25}$ Virchow ${ }^{86}$ and Osler ${ }^{87}$; of the experimental observations of Kocher, ${ }^{88}$ Reverdin, ${ }^{89}$ Stokes, ${ }^{90}$ Gordon, ${ }^{91}$ Horsley ${ }^{92}$ and Halsted ${ }^{93}$; of the therapeutic studies by Murray, ${ }^{94}$ Mackenzie ${ }^{95}$ and von Bruns. ${ }^{96}$

So, also, through the work of St. Lager, ${ }^{97}$ Niepce, ${ }^{98}$ Morel, ${ }^{99}$ Hirsch (loc. cit.), McGarrison ${ }^{35}$ and others, it has been shown that 75 per cent. of all cretins have enlargement of the thyroid clinically, and also that the general relation of goiter to cretinism may be summed up in the words of Morel, that "goiter is the first stage on the road leading to cretinism." From the above generalizations it can be seen that the terms "cretinism" and "myxedema" do not represent simple clinical, anatomical or physiological conditions, but must include all the gradations of the processes of which clinical cretinism and myxedema are the terminal

84. Kocher: Deutsch. Ztschr. f. Chir., 1892, xxxiv, 556.

85. Ord: Brit. Med. Jour., 1888, i, 1162.

86. Virchow: Die krankhaften Geschwülste, 1863; Berl. klin. Wehnschr., 1887, xxiv, 121.

87. Osler: Tr. Cong. Am. Phys, and Surg., 1897, iv, 169.

88. Kocher: Arch. f. klin. Chir., 1883, xxix, 254.

89. Reverdin: Rev. méd, de la Suisse rom., 1882, 539.

90. Stokes: Brit. Med. Jour., 1886, ii, 709.

91. Gordon: Lancet, London, 1886, ii, 65 .

92. Horsley: Lancet, London, 1884, ii, 1133.

93. Halsted: Jour. Exper. Med., 1909, xi, 175.

94. Murray: Lancet, London, 1893, i, 1130.

95. Mackenzie: Lancet, London, 1893, i, 123.

96. Von Bruns: Beitr. z. klin. Chir., 1896, xvi, 521; 1894, xii, 847.

97. St. Lager: Etudes sur les causes du crétinisme, ete., Paris, 1867.

98. Niepce: Traite du goitre et du crêtinisme. Paris, 1851, i.

99. Morel: Du goitre et du crétinisme, etc. Paris, 1864. 
stages. The intermediate stages are best indicated by the various degrees of active thyroid hyperplasia and in an earlier paper one of us (Marine ${ }^{4}$ ) suggested the borrowed term "cretinoid" (Gull ${ }^{23}$ ) as the best descriptive word for the several degrees of hyperplasia seen in dogs, sheep, ox, pig, and human thyroids, since the greater number of these animals having active hyperplasia have no detectable clinical manifestations.

The anatomical changes usually present in typical cretin animals are characterized by the extensive overgrowth of fibrous tissue resulting from the dying off of the epithelial cells. We have not found any definite anatomical descriptions of glands in the early stages of this fibrous tissue replacement of the epithelial hyperplasia. It has been our fortune to observe five cretin puppies and two cretin lambs in which these changes were occurring. As previously mentioned (under anatomical descriptions), the epithelial cells at first enlarge and the nuclei become hyperchromatic. Later these cells become irregular in size and shape and the normally regular outline of the vesicular epithelium is broken. The increased connective tissue crowds out these degenerated cells and finally the vesicle, much reduced in size, becomes filled with the irregular cell masses and the detritus of the more degenerated cells. These changes have been observed only in thyroids of lower animals with clinical manifestations of cretinism. Of perhaps greater interest is the fact that similar disturbances in the nucleus-plasma relations of the epithelial cells have been observed in four cases of exophthalmic goiter which clinically showed manifestations of myxedema.

When these anatomical changes and their clinical associations with cretinism and myxedema are considered together they suggest that the further ability of the cells to grow and divide normally has been seriously disturbed and that the major factors in this disturbance are overrork and lack of proper nutrition, as was pointed out by Popoff ${ }^{100}$ for protozoan cells. In cretin puppies we have been able, by the administration of iodin, to make these cells revert to the flattened cubical form, while the gland as a whole returned to the colloid or resting condition, and later by partial removal to produce a perfectly regular and uniform hyperplasia in the same gland. Professor Howard and Dr. Schultz, to whom we have referred these observations, are of the opinion that these thyroid changes, consisting in the production of depression and the recovery therefrom, are comparable to the protozoan cell changes described by Hertwig and his pupils. The most suggestive explanation at present seems to be that these degenerative and atrophic cell changes are the

100. Popoff: Arch. f. Protistenk. (Suppl.) Festband f. R. Hertwig, 1907, p. 43. 
result of prolonged and unrelieved physiological stimulation to meet some deficiency, and that cretinism and myxedema are the final stages of the failure in compensation.

In view of what has been said above, the earlier statement that in cretinism and myxedema there is a lack of thyroid function is somewhat misleading because the thyroid in the early stages of the process is hyperactive, while, at the same time, the body as a whole suffers from a lack of normal function. Thus it would appear that in the cretinoid and in the myxedematous process the real deficiency lies in the physiological value of the thyroid secretion to the organism. This deficiency may be produced either by atrophy or absence of the gland, or by the absence of the normal elements of nutrition with which the normal metabolic activities of the gland are concerned. Iodin is perhaps one of these elementary deficiencies.

In the true cretin the gland histologically presents marked overgrowth of fibrous tissue, with a corresponding disappearance of the epithelial elements, while in the preclinical stage the gland presents a marked epithelial hyperplasia with relatively slight increase in the supporting fibrous tissue. Thus with the progressive epithelial hyperplasia finally giving way to the fibrous overgrowth as typifying the anatomical changes in the cretin or myxedema thyroid, it may be said that the symptom-complex varies with the degree of epithelial hyperplasia and fibrotic atrophy.

As regards the iodin content in human cretin thyroids no specific cbservations are recorded. In the five cretin dogs examined by us we could find no trace of iodin, and in the four cases of exophthalmic goiter showing clinical signs of myxedema the highest iodin content was 0.544 and the lowest $0.118 \mathrm{mgm}$. per gram of dried gland. This suggests that the iodin content varies inversely with the degree of hyperplasia and fibrosis in both cretin and myxedema glands. With the exception of tumors and infants' thyroids, these were the lowest iodin contents observed. There are variations and modifications in the iodin content and histologic structure of cretin and myxedema glands in man that are comparable to the variations above noted in other clinical varieties of goiter, and depend on the age of the individual, previous medication, the presence of complicating and degenerative changes, etc. These variations and modifications we believe could be easily explained if the lifehistory of such patients could be accurately ascertained. But, as this at present is quite impossible, our hope lies in the accumulation of sufficient cases to include all the variations and the essential types of change as well. 
In conclusion we believe that the various degrees of thyroid hyperplasia are but stages in a common process the final result of which is cretinism or myxedema and that the percentage of iodin varies inversely with the degree of hyperplasia and fibrosis.

\section{CONCLUSIONS}

1. Active thyroid hyperplasia is present in all developing goiters in all animals.

2. All thyroid hyperplasia, so far as we can determine, is anatomically, chemically (iodin) and biologically the same.

3. Thyroid hyperplasia develops in both normal and colloid glands.

4. Colloid glands, anatomically, chemically and biologically, are the nearest approach to the normal gland that hyperplasias can become and obey all the known biological laws of normal glands in so far as these laws are at present known.

6. The various degenerations, hemorrhages and cysts are secondary and complicating changes engrafted on to the three fundamental types of normal, hyperplastic and colloid glands.

7. Iodin is necessary for normal thyroid activity.

8. The iodin content varies inversely with the degree of hyperplasia.

9. The percentage of iodin present in thyroids is variable, but there is a quite constant minimum percentage necessary for the maintenance of rormal or colloid gland structure.

10. Iodin is taken up rapidly by the thyroid, the rapidity depending on the degree of active hyperplasia.

11. Mild degrees of thyroid hyperplasia accompany or follow many of the chronic nutritional disturbances without detectable clinical symptoms referable to the thyroid.

12. Exophthalmic goiter is constantly accompanied during the progressive stage of the disease by thyroid hyperplasia and the iodin percentage varies inversely with the degree of hyperplasia.

13. In endemic cretinism the fibrous overgrowth with atrophy of the gland cells is consequent on active hyperplasia and is associated with a very low iodin content.

14. In myxedema the anatomical and iodin changes are similar to those of cretinism.

We wish to acknowledge our indebtedness to Prof. W. T. Howard for the anatomical material; to Prof. G. W. Crile for his surgical material at Lakeside Hospital, and also to thank Professors Howard and G. N. Stewart for their careful criticisms and suggestions. 